\title{
THE IMPACT OF SOUTH ASIAN CULTURAL VIOLENCE
}

by

Riti Dass, BA, York University, 2012

BSW, Dalhousie University, 2015

\author{
An MRP \\ presented to Ryerson University \\ in partial fulfillment of the \\ requirements for the degree of \\ Master of Social Work \\ in the Program of \\ Social Work
}

Toronto, Ontario, Canada, 2018

(C) Riti Dass 2018 
AUTHOR'S DECLARATION FOR ELECTRONIC SUBMISSION OF A MRP

I hereby declare that I am the sole author of this MRP. This is a true copy of the MRP, including any required final revisions.

I authorize Ryerson University to lend this MRP to other institutions or individuals for the purpose of scholarly research

I further authorize Ryerson University to reproduce this MRP by photocopying or by other means, in total or in part, at the request of other institutions or individuals for the purpose of scholarly research.

I understand that my MRP may be made electronically available to the public. 


\author{
ABSTRACT \\ The Impact of South Asian Cultural Violence \\ Master of Social Work, 2018 \\ Riti Dass \\ Program of Social Work, \\ Ryerson University
}

This study explores the experiences and perspectives of first/second generation South Asian Canadian women on the representation of South Asian culture and violence against South Asian women. Specifically, this study looks at the myth of South Asian cultural violence, which views South Asian culture as inherently oppressive toward women and South Asian men as violent; and as a result, South Asian women are seen as victims of these men and their culture. This study does not undermine violence against South Asian women, but challenges the ways in which violence against South Asian women gets talked about through the myth or the discourse of South Asian cultural violence. Both the state and (trans)national media play an important role in circulating this myth to further socio-political agendas. Centering the narratives of South Asian women in this study will show the ways in which they make meaning of the myth, as well as how they challenge and resist it. This study involves a focus group with two first/second generation South Asian Canadian women using arts-informed narrative methodology. Findings demonstrate that the discourse of South Asian cultural violence has had a significant impact on their relationship to themselves, other South Asians, and to the South Asian culture due to the ongoing encounter with stories of violence against South Asian women. 


\section{ACKNOWLEDGEMENTS}

First and foremost, I acknowledge the participants of this study who shared their time, knowledge, and experience with me. My vision of this project could not have come to fruition without support from Dr. Samantha Wehbi, who also opened my mind to vast possibility of incorporating arts and social work. I also would like to thank my family for believing in me and supporting me in completing this project. Finally, thanks to my colleague and friend, Erinn Oh, whose time and consistent encouragement sustained my dedication to this project. 


\section{DEDICATION}

To my mother, may this honour your story and your ongoing resistance. 


\section{TABLE OF CONTENTS}

CHAPTER 1. INTRODUCTION \& THEORETICAL FRAMEWORK ................................... 1

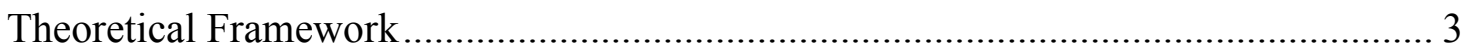

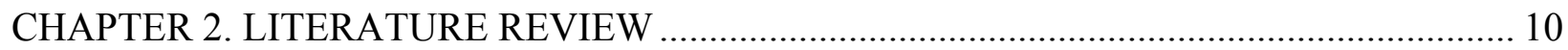

South Asian Immigrant Women and Domestic Violence........................................ 11

South Asian Cultural Violence and Young South Asian Women ............................... 12

Critical Perspective on the Discourse of South Asian Cultural Violence...................... 14

Research That Centers Voices of South Asian Canadian Women ................................ 19

Research Gaps........................................................................................... 20

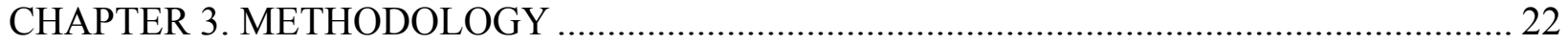

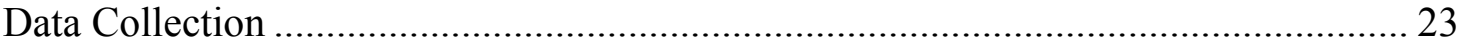

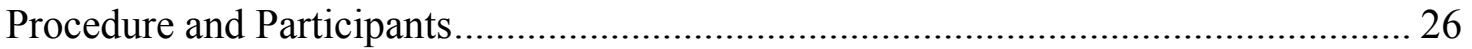

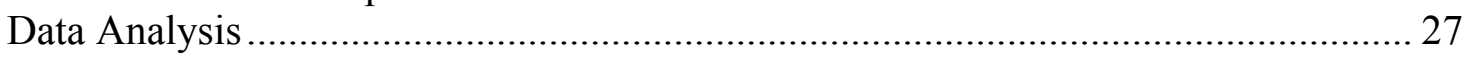

CHAPTER 4. FINDINGS AND DISCUSSION ............................................................. 29

Weaving and Layering of Our Collective Experiences .......................................... 29

Treading tightrope as first/second generation South Asian Canadian women ............ 35

Warriorhood of First/Second Generation South Asian Canadian Women ................... 44

CHAPTER 5. CONCLUSION: IMPLICATIONS, STRENTGHS \& LIMITATIONS ............... 51

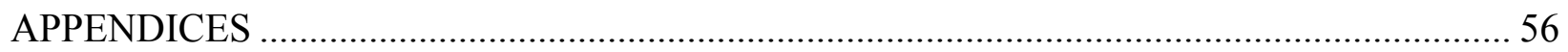

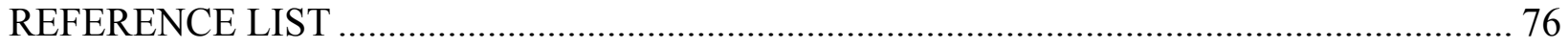




\section{LIST OF FIGURES}

Figure 1 - Theoretical lenses

Page 9 


\section{LIST OF APPENDICES}

Appendix A - Recruitment email

Page 56

Appendix B - Consent form

Page 58

Appendix C - Resource list

Page 62

Appendix D - Interview Guide

Page 66

Appendix E - Images of the Collage

Page 68

Appendix F - Participants' Collages

Page 73

Appendix G - Ethics Clearance Certificate

Page 75 


\section{CHAPTER 1. INTRODUCTION \& THEORETICAL FRAMEWORK}

As a first generation, South Asian Canadian woman, my life has been saturated with stories of violence against South Asian women. These stories of violence have been used against my family, my culture, and myself. Herein lies the discourse that South Asian culture is inherently patriarchal, and South Asian women and girls are victims of their culture and predestined to the violent nature of the South Asian men. This MRP explores this discourse through the experiences and perspectives of first/second generation South Asian Canadian women by looking at the myth of South Asian cultural violence, which views South Asian culture as inherently oppressive toward women and South Asian men as violent. This study is not attempting to undermine violence against South Asian women, but attempting to challenge the ways in which violence against South Asian women gets talked about through the myth or the discourse of South Asian cultural violence.

The media plays an important role in circulating the discourse of South Asian cultural violence by sensationalizing stories of violence against South Asian women and girls (Durham, 2015; Grewal, 2013; Jiwani, 2006; Olwan, 2013; Patil \& Purkayastha, 2015; Shier \& Shor, 2016). These stories of South Asian cultural violence have been deeply etched into my memory, and I recall from a very young age believing that my culture was inherently patriarchal and violent. Such problematic view of my culture and my people impacted me negatively, especially as it related to myself as South Asian. My goal for this MRP is to know how other South Asian women experience this discourse and ways in which they have been impacted by it. It is only recently that I have developed the language to challenge such discourse. However, media continues to play a role in reinforcing the discourse of South Asian cultural violence. As a social 
worker, it is important for me to challenge this discourse and to engage other social workers in discussions about it.

Furthermore, locating this discourse within the post-September 11, 2001 context I understand that this discourse is used to circulate problematic ideas about South Asian communities, especially South Asian Muslims. Within this discourse, young women are distinctly positioned because it is their stories of violence that become a marker of the nationstate. The subjectification of these women is also different than the previous generation because unlike the immigrant subject whose identity was pre-established within the nationhood of their country of origin, these young women's belongingness within the Canadian nationhood is questioned (Aujila, 2000; Rajiva, 2006).

Within Canada the media uses the stories of violence against South Asian women to circulate ideas about immigration, belonging, and assimilation (Olwan, 2013). These stories have an impact on policies and practices involving immigration and the South Asian community. Explicitly, the bodies of dead young Muslim women are used to exalt Canadian nationhood and strengthen the techniques of border management and control (Thobani, 2007). For example, Canadian citizenship book includes the direct statement against gender-based violence that is attributed to cultural practices of immigrants (Olwan, 2013). Related to this was passing of Bill S-7 “Zero Tolerance for Barbaric Cultural Practices Act.” Making Bill S-7 into a law (METRAC, 2015) and allocating 2.8 million dollars to the South Asian community, while cutting funding from Indigenous women's associations are part of a larger impact that this discourse has had in Canada (Olwan, 2013). These policies and practices show that it is not just immigrant and South Asian communities that are impacted by this discourse, but the violence on the bodies of young South Asian women is used to justify further oppression of Indigenous 
communities by the Canadian government. Therefore, within Canada, both the media and the state work together to magnify issues of South Asian communities at an expense of another.

The policies along with essentialist representations situate social workers within a system that reinforces the harmful discourses about South Asian communities and their culture.

Centering the voices of those who have been impacted by the discourse can potentially challenge the dominant hegemonic narrative that individuals, both within and outside of the field of social work, hold. More specifically, my hope is that this will encourage social workers to shift the ways in which they talk about violence against South Asian women.

\section{Theoretical Framework}

This research project is grounded in the theoretical framework of transnational feminism and coloniality of power. Both theoretical approaches provide lenses through which to better understand the discourses of violence surrounding South Asian communities.

\section{Transnational Feminism}

Transnational feminism connects the local and global context of the struggles of marginalized women. It is not an attempt to universalize the experiences of women, instead it is a challenge to the:

hegemonic feminist solidarity project based on narrow, middle-class, first world, heterosexual notions of gender-based on US notions of exceptionalism, empire, and patronizing missionary position that believed, and believes without question that liberation movements of all stripes — gay, feminist, racial—are US creations that benevolently travel to far off places to liberate the downtrodden across the globe. (Blackwell, Briggs, \& Chiu, 2015, p. 7) 
This thinking attempts to extend the idea of a "global sisterhood" approach (Blackwell et al., p. 2). Transnational feminism as a political framework acknowledges that oppression based on gender cannot be separated from dialogue about other forms of geopolitical, colonial, and material economic, racial, gender, and sexual oppression (Blackwell et al., 2015; Kaplan \& Grewal, 1999). This theoretical perspective holds that there are multiple and interlocking kinds of power relations that affect women's lives within and across national boundaries, including economic, heteropatriarchal, white supremacist, and ableist domination (Blackwell et al., 2015).

As well, the "trans" within transnational surfaces a different relationship to the nation than the comparative or international analysis because these latter approaches re-centre the nation as the unit of comparison (Alarcon, Kaplan, \& Moallem, 1999). Bringing nation-state within the dialogue about subjectification of South Asian women is important because it is this subjectification that is used to mark boundaries around nation-state to determine who belongs in the nationhood (Blackwell et al., 2015). Therefore, the trans within this project recognizes that there are discursive tactics taking place within geopolitical spaces to include and exclude certain bodies from one nation-state to another. This is to say that within a post-colonial context, the types of discourses about violence against South Asian women are used to reinforce the white colonial capitalist projects, both in the West and in the South Asian countries.

Within this analysis, a post-colonial context is used to refer to ongoing forms of colonialism that have sustained even after the departure of colonial government in certain regions. I also acknowledge that here in Canada colonizers never left and the settler colonialism continues to mold the fabric of Canada for Indigenous peoples, both white settlers, and racialized immigrants continue to serve the project of colonialism (Thobani, 2007). As such, transnational 
feminism enables me to weave in stories of violence against South Asian women because it perpetuates an ongoing colonial project.

\section{Coloniality of Power}

I am also concerned with the ways in which we talk about violence against South Asian women, that even in spaces that attempt to disrupt the dominant narratives about South Asian culture can perpetuate racist colonial beliefs about us and our culture. So how do we talk about stories of violence without locating them within a problematic culture and not falling in the trap of erasing the experiences of survivors? For me, the post-colonial lens within transnational feminism gives me such language and tools to answer the above question. As such, I am combining a post-colonial lens within this framework to not only acknowledge the post-colonial realities of South Asians but also trace the history of the discourse and its potential impact back to the imperialism of British Raj. It is this history that continues to echo in the post-colonial present. When I say echoing of history I do not just mean that in our present there is manifestation of past colonial memories. I also mean that the history continues to structure our realities. To understand this further I use the theory of coloniality of power by the Latin American scholar Maria Lugones (2008).

Lugones (2008) expanded Anibal Quijano's (2001) concept of coloniality of power from an intersectional feminist lens to include coloniality of gender. From this perspective, Coloniality of power examines the modern regimes of global power from a rationality of Eurocentricism. It is different than the previous domination of the empire over colonies, yet rooted in colonial histories and "proven to be more durable and stable than the colonialism in whose matrix it was established" to manifest itself differently in time and space (Quijano, 2001, p.533). This conceptualization outlines the constructed hierarchies based on differences- including but not 
limited to race, gender, class- established within the world-system (Quijano, 2001). This has farreaching implications and it affects all aspects of our lives, including "sexual access, collective authority, labour, subjectivity/inter-subjectivity and the production of knowledge from within these inter-subjective relations" (Lugones, 2008, p.3). It is not that these differences did not exist prior to the colonial encounter but the colonizers established hierarchal structures to deal with these differences. With the worldwide expansion of European colonial domination, the classification and axes of systems of power were imposed on all the population of the planet.

Maria Lugones (2008) expands the coloniality of power from an intersectional lens to explicitly emphasize the unequal gender hierarchy created between racialized women and men, a structure created to perpetuate systematic violence against racialized women. Lugones (2008) makes it clear that the gender difference was imposed on us as racialized people, and as such violence against racialized women can be traced to colonialism which continues to (re)produced through coloniality of gender. Understanding this theory for me is helpful in talking about violence that often gets located within the logic of inherently patriarchal culture and violent barbaric men. As Lugones puts it this makes "visible the instrumentality of the colonial/modern gender system in subjecting us - both women and men of colour - in all domains of existence" (p.1). Furthermore, I agree with Lugones that locating violence and gender difference rooted in the coloniality of gender enables us as racialized people to disrupt the structure that hinders our solidarity. Following this logic, this perspective has a potential for us to challenge allegiance to cis-hetero-patriarchal gender system to transform our communal relations (Lugones, 2008).

Specifically, for this MRP, I use Jose David Saldivar's reading of Arundhati Roy's book God of Small Things to capture the concept of coloniality of power and gender. The novel surfaces how the coloniality of power dictates the local love laws and configures our relations. 
The local love laws, articulated by Roy, mark the boundaries around "who should be loved and how and how much" as it relates to heteronormative issues of family, bloodlines, and the caste structure (Roy, 1997, p.168). Saldivar (2007) in his essay about unsettling coloniality through narratives, uses Roy's writings on "the memories of violence and identity... to help us think through the 'colonial difference' in a more global framework,"” and to question "how to live within the context of global coloniality?" (Saldivar, 2007, p.358). Within the context of this project, I extend this idea of love laws not just in terms of relationships, but also to our understanding and connections to ourselves, others, and our culture considering the hierarchal differences that permeate our lives.

I also connect the love laws to the concept of "encounters" articulated by Sara Ahmed in the context of the post-coloniality. Encounters, acts of meeting another, are historically and socially situated and marked by relationships of power that manifest past colonial encounters (Ahmed, 2000, p.8). Thinking about encounters from a coloniality of power lens, I would argue that these encounters do not just unfold past colonial encounters but they also (re)produce the hierarchies and differences of colonial structures. Here, I am interested in encounters with stories of violence against South Asian women, as well as ourselves as South Asians, our community, and our culture. Moreover, what is the impact of these encounters that are rooted in the discourse of South Asian cultural violence, whether through media or face-to-face interactions?

Related to the concept of encounters, Indrepal Grewal (2013) conceptualized a discursive tactic called "outsourcing patriarchy." This concept is rooted in colonial and orientalist assumptions that the West/Global North is better than East/Global South; this reflects and reinforces the idea that the West buy into the belief that patriarchy no longer exists in the West 
and in white communities, and if it does, then it is not reflective of the whole nation. According to Grewal (2013):

the profits are material in a number of ways: from fiscal, to the production of narratives that circulate transnationally, to the use of the term in regions to which outsourcing is done (such as India), to the wars fought ostensibly to 'save brown women from brown men" (p. 2).

Here, women's rights and women's issues are used as a yardstick to measure progress, equality, and modernism. The West holds this claim by the participation of media and the State of transporting patriarchy within Global South and migrant communities in the North from the Global South, and by surfacing stories of violence against women within those communities and countries. Thus, the Northern white world exalts itself of violence toward women and patriarchy, simultaneously reinforcing a white saviour complex to rescue young South Asian women from their families and culture.

In keeping with a lens that recognizes the resistance of women to oppressive discourses, I also rely in this MRP on the concept of anti-essentialism. As articulated by Razack (1998), I rely on the concept to understand that South Asian women are not passive recipients of this discourse; they also challenge and resist the discourse in multiple ways. The anti-essentialist representation of themselves and their culture also surfaces the complexities that in turn challenges the discourse of South Asian cultural violence. It is my hope in this MRP to not only understand how discourses of South Asian violence affect women, but also how women challenge these discourses. The following figure summarizes and illustrates the theoretical concepts underlying this MRP working together to form a subjectification and resistance of South Asian women. 
Figure 1. Theoretical Lenses

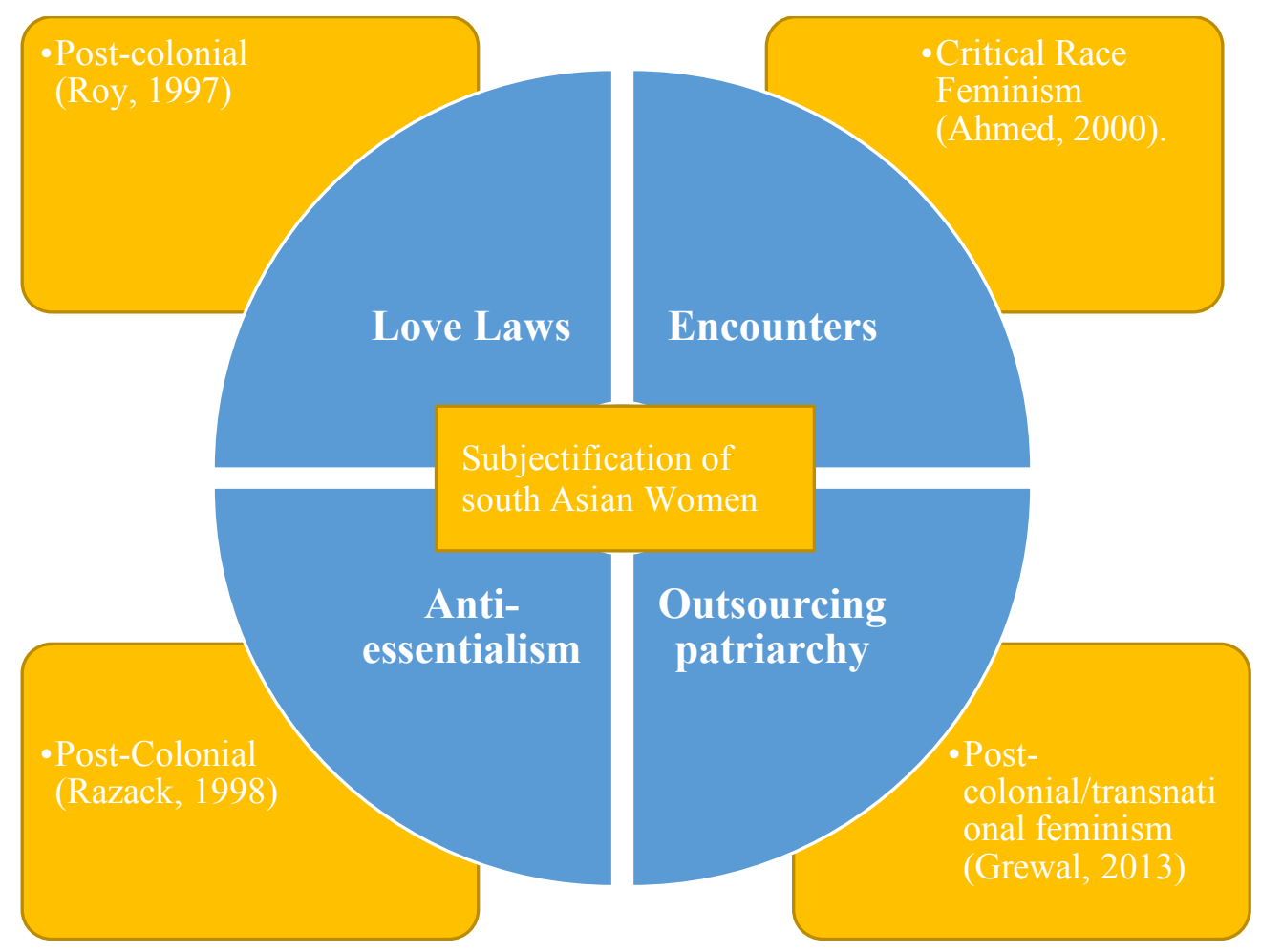




\section{CHAPTER 2. LITERATURE REVIEW}

Within this literature review, I will first discuss the impact of the discourse of South Asian cultural violence within Canada, then give an overview of the research literature on violence related to South Asian women. Specifically, my literature search includes various ways violence has been discussed within research in relation to multigenerational South Asian women in the West, and more closely in Canada. In addition, I will examine research on transnational media portrayal of South Asian women and their experiences of violence. I am particularly interested in the subjectivities of first/second generation South Asian women in the West, and young South Asian women in South Asian countries.

Through this literature review, I aim to bring together various bodies of research on violence against South Asian women to locate it within the discourse of South Asian cultural violence using the lens of transnational feminism in the context of post-colonialism. I have categorized themes from the literature based on the perspective that research acts as knowledge production (Pascale, 2011). As such, the themes illustrate the ways in which violence against women has been talked about within the scholarship. From this perspective, studies are reflexive of the dominant hegemonic culture that acts as a source of knowledge production of South Asian people and culture, which validate and reproduce existing social hierarchies by locating the problem of violence within the individual, family, community, and their culture. The themes include 1) South Asian immigrant women and domestic violence; 2) South Asian cultural violence and young South Asian women; 3) Critical perspective on the discourse of South Asian cultural violence; and 4) research that centers voices of South Asian Canadian women. The last theme is not directly about violence against women; however, I relate the theme to racism, 
assimilation, and belonging resulting from the same hegemonic culture that perpetuates the discourse of South Asian cultural violence.

\section{South Asian Immigrant Women and Domestic Violence}

Within the literature, there is extensive research on South Asian women and violence. Many of these studies tend to focus on South Asian immigrant women and their experiences of domestic violence (Ahmad, Riaz, Barata, \& Stewart, 2004; Bhatt, 2008; Mason, Hyman, Berman, Guruge, \& Kanagarantnam, 2008; Menjivar \& Salcido, 2002). Some studies on South Asian immigrant women's experiences with domestic violence are embedded in the assumptions that South Asian culture is inherently violent and emphasize the vulnerability of immigrant women (Ahmad et al., 2004; Chaudhuri, Morash, \& Yingling, 2014).

For example, a study by Ahmad et al. (2004) examined the relationship between South Asian immigrant women's acceptance of patriarchal norms and their perceptions of abuse. Even though this study recognizes the intersectionality of identities, Ahmad et al. (2004) used a white Eurocentric feminist lens that assumes that South Asian culture is patriarchal. This essentialist notion of South Asian culture suggests that "woman's acceptance of patriarchal norms predicts their own perception of what is spousal abuse" (Ahmad et al., 2004, p. 275). Such research findings, reinforce the discourse of South Asian cultural violence because the study uses white Eurocentrism as a reference point, which leads to a "common sense" view of South Asian women as a product of their culture that socializes them to be submissive and teaches them that spousal abuse is the norm. Therefore, this study blames them and their culture for not seeing their own abuse as problematic. 


\section{South Asian Cultural Violence and Young South Asian Women}

The second theme found within the literature includes studies that take the perspective of young South Asian women and their perception of gender oppression and violence, more specifically these studies involve first/second generation South Asian women in diaspora (Devdas \& Rubin, 2007; Gilbert, Gilbert, \& Sanghera, 2004). These studies look at various ways in which young South Asian women have internalized patriarchal beliefs, and this belief is again attributed to their culture.

A study by Gilbert et al., (2004) illustrates that mental health problems are related to the practice of honour and shame embedded within the hierarchal structure of the South Asian family. It is this structure that makes South Asian women experience 'entrapment,' which leads to an array of other issues such as lack of help-seeking for their mental health concerns (Gilbert et al., 2004). Another study illustrated that first-generation South Asian American women blamed the cause of rape on the survivor significantly higher than second-generation South Asian American women and "European American" women (Devdas \& Rubin, 2007). In the former study, it is the individual's "acculturation" that is a mitigating factor for accepting the rape myth, whereas, in the latter study women's resistance to the traditional social order mitigates their entrapment. In both cases, the issue of violence against women is individualized and follows a common-sense logic of binary between South Asian culture and Western culture; that it is the patriarchal nature of the South Asian culture that creates these issues for these women and the only solution to fight against that culture is to incorporate or assimilate into the Western culture. The studies go on to articulate that these young women have limited helpseeking behaviours because they do not understand or view their situation through the lens of Western or Eurocentric belief about women's equality. However, such logic individualizes the 
issue and holds the South Asian women accountable for their own victimhood. Following an essentialist notion of South Asian culture, these authors encourage helping professionals to learn about the South Asian culture and the context of women within the culture. The implication is problematic because the individual differences and larger societal barriers that these participants face in seeking help are overlooked; rather they argue that the barriers are due to the individuals, not the system itself. Furthermore, locating culture as the site of the issue can legitimize that service providers can avoid dealing with problems of violence within specific minoritized communities that follow discourse of 'cultural privacy' or 'cultural respect' or 'keeping it in the family' (Ahmed, Reavey, \& Majumdar, 2009).

While the above studies attempt to indirectly link the role of culture to recognizing one's own and other's oppression and violence, there are other studies that consider the direct link. Ahmed et al. (2009), for example, attempt to directly look at the role of culture and understanding one's own experiences of violence as a South Asian woman. Specifically, this study considers the ways in which British-born South Asian women survivors of sexual violence in an intimate partner relationship makes sense of their experiences in relation to the notions of culture or 'culture discourse' (Ahmed et al., 2009). Here, the authors demonstrate how the participants internalize and reproduce taken for granted assumptions about South Asian culture as "problematic and unchangeable" (p. 14). These participants attributed their experiences of violence and the lack of support from family and community to culture. While these women challenged the static notion of the culture and their positionality as a daughter and a wife, neither researchers nor the participants named this resistance as part of these women's culture; this act is seen as separate from their culture. Therefore, even in an attempt to problematize culture as the site of the problem, there is no room to name these alternative experiences of resistance within a 
frame of culture; as such, the hegemonic discourse about South Asian culture are left unchallenged. Here, again South Asian culture is spoken as a synonym for patriarchy and the actions of South Asian women are placed against their culture, instead of being articulated as resistance toward patriarchy.

\section{Critical Perspective on the Discourse of South Asian Cultural Violence}

While certain studies (re)produce the discourse of the South Asian cultural violence, there are also studies that counter this discourse. These critical perspective studies examine discourses and discursive practices that operate to reproduce the knowledge about South Asian women and the dominant culture's understanding of the violence they experience (Ahmad, Erickson, \& Stewart, 2013; Bhatt, 2008; Mason et al., 2008; Menjivar \& Salcido, 2002; Shankar et al., 2013). These studies contribute to the growing body of knowledge in deconstructing the dominant narrative about South Asian women and their culture. The studies pose a challenge to the belief that incidences of violence among South Asian women are significantly higher than that of the non-South Asian population (Manjivar \& Salcido, 2002). Furthermore, these studies disrupt the singular story that the violence that South Asian women experience is caused by their culture and examines various other contributing factors, such as the larger socio-political and economic context of their lives. For example, the analysis of the literature on the prevalence of domestic violence among South Asian immigrant women, by Menjivar and Salcido (2002), attributed their vulnerability to structural barriers related to language skills, isolation, lack of access to a dignified job, and uncertain legal status.

In an attempt to debunk the myth of the South Asian cultural violence, Shankar et al. (2013) used critical discourse analysis of ancient Indian texts to illustrate that the dominant discourse about male superiority that increased women's vulnerability to violence can be 
attributed to multiple social and environmental factors within a rapidly changing sociopolitical climate that shifted women's equal position within the South Asian society. Shankar et al.'s (2013) approach is especially intriguing as it shows the creative ways that research can challenge dominant discourse. Comparing this study (Shankar et al., 2013) to other studies on South Asian women and domestic violence, this study goes to the root of South Asian culture by looking at the ancient text to debunk the myth that the culture itself is oppressive of women. However, caution should be used in relying on this study because it can be misused to reinforce Islamophobia since the research only looked at Hindu text and not Muslim text. The text examined for the study predated Mughal conquest and introduction to Islam in South Asia, and hence the findings could be misused to suggest that South Asian culture became inherently violent after this context. Nevertheless, the strength of the study lies in the method and the analysis of the text through which researchers surfaced the context and social conditions that make the position of the women vulnerable in South Asia.

The current context of hegemonic patriarchy and violence against women in South Asian countries is examined by Chowdhury (2015). Chowdhury connected the incidence of acid attacks in Bangladesh to the current geopolitical transnational landscape; the author argued that the violence against women and girls in South Asia, especially acid attacks, must be understood considering political, socioeconomic, and historical forces that work together to make certain social groups more vulnerable to extreme forms of violence and suffering. Through her evaluation of non-governmental organization (NGO) reports, the author illustrates that such acts of violence are limited but are articulated from a racial and class bias that evokes common sense logic. Chowdhury also points out that naming violence as stemming from hegemonic masculinity and patriarchy erases multiple factors that create a context for violence against women, which is 
used to shape the response of the state and transnational activist networks to further marginalize poor communities in Bangladesh.

Like Chowdhury's (2015) study, several other research studies evaluate the discursive strategies used by media; another source that plays a major role in circulating the stories of violence against South Asian women. These studies emphasize the role that media plays in portraying South Asian women as vulnerable who need to be rescued from the barbaric South Asian men and their inherently patriarchal culture (Durham, 2015; Grewal, 2013; Patil \& Purkayastha, 2015; Roychowdhury, 2013). These studies have considered the role that media has played in their coverage of two different cases which received transnational attention. The findings of the studies are relevant to this topic because these studies demonstrate the ways in which media circulates and strengthen discourse related to the stories of violence against south Asian women. These two cases include the story of Jyoti Singh Pandey in New Delhi, India (Durham, 2015; Roychowdhury, 2013) and Shafia trials in Canada (Olwan, 2013).

The important findings from the critical discourse analysis of the media, illustrate that there was a significant increase in the coverage of both cases compared to cases involving violence against white women in the Global North (Patil \& Purkayastha, 2015; Grewal, 2013; Olwan, 2013). Specifically, Patil and Purkayastha (2015) compared media's treatment of the Pandey's experience of rape, a local Indian woman in New Delhi, India, and the rape of a white woman in Steubenville, USA, found that the racialized Indian woman's story was 'hyper-visible' (p.598) in the transnational media, while the white US woman is relatively invisible. The relative invisibility of the Steubenville case demonstrates the protection that the white woman received from eyes of the media, in contrast to the New Delhi case in which media repeatedly 
exploited the violence against Pandey to make a point that there is a significantly increased violence in India.

While the transnational media focused on discursive strategy of reporting frequency of violence against women, the Canadian news media's discursive strategy included pairing the frequency of the violence taking place within the South Asian communities to the ideologically loaded term "honour violence or killing" (Olwan, 2013; Grewal, 2013; Sheir and Shor, 2015). Study by Sheir and Shor (2015) found that although "articles reporting family murders remained fairly stable (200-300 in most years) there has been a significant steady increase in reporting on 'honour killings.' (p. 1170).

Another tactic that news media uses to show that there is increased violence in the South Asian communities is that the coverage of incidences of violence were never stand-alone cases (Durham, 2015). News stories on the two cases surfaced multiple other cases of rape, acid attacks, and other types of violence to make a point that South Asia has increased amount of violence against women compared to the Western countries. In Durham's examination of the first two weeks of coverage of the New Delhi rape case, "rape itself was never a stand-alone incident worthy of news attention" (p. 182). Similarly, Patil and Purkayastha (2015), found that news media frequently referenced other rape cases to New Delhi rape case, as well as connected the incidence to different types of violence against Indian women, such as acid attacks. This strategy is also evident in the coverage of 'honour violence' among South Asian immigrant communities in the West (Grewal, 2013).

Another pattern that these studies surfaced within their evaluation of the media's coverage of these cases is that the media often focused on specific subjects. In both the coverage of Shafia trials and New Delhi rape case, the media repeatedly focused on the young women 
(Olwan, 2013; Roychowdhury, 2013). This was often tied with surfacing the ways in which these young women demonstrated 'modern' and 'Western' believes and behaviours. This was generally juxtaposed with an increased focus on Brown men or the Brown families that perpetrated that violence and exhibiting their 'traditional' worldviews. Both Olwan's (2013) analysis of media's coverage of Shafia trials and Roychowdhury's (2013) analysis of media's coverage of Pandey's story, argue that as these two types of subjects, the young Brown women and the Brown men/families, become increasingly visible the others' experience within the story becomes invisible. When the media focuses largely on the violence against women within racialized immigrant communities as well as in the Global South by racialized men, simultaneously minimizing the violence against women perpetrated by white men that takes place outside of these two settings, the implication bestows that the violence against women and patriarchy ultimately lies 'there' in the Global South or the communities from Global South, and 'here' the Global North is safe and free from patriarchy and violence against women (Grewal, 2013).

While these studies on violence against South Asian women have challenged and deconstructed dominant discourse and discursive practices, they do lack the voice of first/second generation South Asian Canadian women. However, within the critical discourse studies, South Asian Canadian women remain a subject. How the discourse about South Asian cultural violence impacts them at a personal level remains unknown within the literature. Their voices are only deemed valid when they are the victims of that violence, as illustrated in the earlier section, South Asian cultural violence reinforced by research with young South Asian women. 


\section{Research That Centers Voices of South Asian Canadian Women}

The studies that challenge the dominant discourse about South Asian culture and effectively centre the narratives of young South Asian women in Canada, without reinforcing harmful discourses, include the studies of assimilation and belonging (Aujla, 2000; Rajiva, 2006). While these studies do not directly address the discourse of the South Asian cultural violence or violence against South Asian women, they do surface intersectionality of first/second generation South Asian Canadian women. The focus on the identity of South Asian Canadian women, specifically first/second generation is important because their sense of self is based on being different and being Othered in the Canadian nationhood (Aujila, 2000; Rajiva, 2006).

Therefore, the studies on assimilation and belonging attempt to surface gendered forms of racism experienced by these women, within the post-colonial context of multicultural Canada. These studies demonstrate the ways in which interlocking systems of power play out in women's lives, to facilitate the process of Othering at both an interpersonal and structural level. This then contributes to their struggle in making sense of who they are, and who they want to be while attempting to belong to both peer culture and popular culture (Aujla, 2000; Rajiva, 2006). These studies demonstrate how racism and assimilation are an ongoing part of women's lives and that there is an array of discourses that contribute to their oppression and social location; linking the discourse of South Asian cultural violence is just part of this larger puzzle.

These studies are also unique relative to the previous studies because they attempt to consider complex ways that racism works, while simultaneously unmasking creative ways South Asian women resist and challenge their marginalization. For example, Malhi and Boon (2007) found that South Asian Canadian women used the same rhetorical strategies and discursive devices to cope with racism as the ones that they encountered in racist encounters. Aujla (2000) 
also points out that multigenerational South Asian Canadian women addressed the issues of racism by producing literary text to form alternative identities. Most importantly, these studies (Aujla, 2000; Beharry \& Crozier, 2008; Malhi \& Boon, 2007; Rajiva, 2006) illustrated that South Asian Canadian women are not passive recipients of racism and harmful discourses, instead, they are active agents in understanding and addressing their and others' marginalization. For example, participants in Beharry and Crozier's (2008) study were able to name their experiences as racism, and participants from Rajiva's (2006) study were simultaneously able to name racism experiences by themselves and others. Furthermore, these participants were able to connect their personal experiences of racism to the larger socio-political context.

\section{Research Gaps}

The studies discussed in the literature review help us to understand, 1) how and why transnational media, the State, and research circulate discourse of South Asian cultural violence; 2) how South Asian women perceive their violence because of the internalization of their oppression; 3) how South Asian women are situated and connected within the transnational and national space; and 4) how South Asian Canadian women play an active role in challenging racism within the dominant white society. However, these studies do not directly examine how South Asian Canadian women make sense of the discourse of South Asian cultural violence and the various ways they challenge and resist this discourse, regardless of whether they have experienced violence themselves or not.

If the previous studies on the critical discourse analysis of the media on South Asian cultural violence suggest that such discourse impacts South Asian women's position in the national and transnational space, then it is important to examine how this rhetoric of South Asian cultural violence impacts them at a personal level. This is especially relevant to first/second 
generation South Asian Canadian women because this discourse is used to pit them against their families and their culture (Olwan, 2013). Furthermore, it is the violence they experience and their bodies that are used to mark the boundaries around the nation-state (Olwan, 2013; Thobani, 2007). Most of the studies that have successfully attempted to deconstruct this discourse have used a variation of critical discourse analysis methodology. However, within these studies, South Asian women remain a subject. This methodological gap impacts the process of research as well the outcome of studies. Therefore, incorporating narratives of South Asian women will show the ways in which they internalize and understand the discourse, but also how they challenge and resist it. Furthermore, this will open a window into how first/second generation South Asian Canadian women create alternative narratives and different ways of being in the context of globalization and post-colonialism, that echoes the colonial past through hegemonic patriarchy and gendered racism in multicultural Canada.

Taking the preceding discussion into account, this study asks: what is the impact of the stories of South Asian cultural violence on first/second generation South Asian Canadian women, and specifically, how do they see themselves and their culture in relation to these stories? As well how do they challenge and resist this myth in their lives? 


\section{CHAPTER 3. METHODOLOGY}

This study integrates storytelling with collage within an overarching methodology of artsinformed narrative inquiry. According to Leavy (2009) epistemologically and methodologically artists and qualitative researchers share similarities in terms of desire to "illuminate something about the social world, sensitively portray people and their circumstances, develop new insights about the relationships between our sociohistorical environment and our lives, or disrupt dominant narratives and challenge biases" (p.17). The main methodology of narrative inquiry combines art to guide certain aspects of my research. The assumptions behind this type of methodology holds that research is informed by art (arts-informed research) but not based in the arts (Knowles \& Cole, 2008). My intention of using arts-informed research is related to its capacity to reach diverse audience and increase accessibility of the knowledge produced because it integrates "alternative processes and representational forms of inquiry" compared to the dominant or conventional ways of doing research (Knowles \& Cole, 2008, p.59). Using artsinformed methodology also in a way redefines or challenges dominant research forms. It allows both the researcher and the audience to unmask "a new understanding of process, spirit, purpose, subjectivities, emotion, responsiveness, and the ethical dimensions of inquiry" (Knowles \& Cole, 2008, p.59).

There are several defining elements of arts-informed research including a commitment to a particular art form, methodological integrity, researcher-as-artist, reflexivity, and centrality of audience engagement (Knowles \& Cole, 2008). Based on these elements, this research used collage as an art form, to move beyond textual or verbal utterances, especially when examining personal stories/narratives. Following the concept of aesthetic knowing, the arts are used as a tool to disrupt the "ordinary" which can surface different ways of knowing and being not 
necessarily captured just by text or spoken narratives. This approach also captures different ways of becoming, which highlights the complexities and multiplicities embedded in narratives and identities (Leavy, 2009).

The inspiration for this methodology stemmed from the South Asian garment, the sari. Sari for me relates to this concept of South Asian self in terms of how the six to nine yards of fabric, quite historical in its origin, can be draped in multiple ways. It is also intriguing for me that saris made from traditional fabric can be worn in contemporary ways and contemporary fabric can be worn in a traditional fashion. It is this remaking of the traditional garment while holding it true to its essence is something that I wanted to capture within this project in terms of ourselves as South Asian women within the diasporic landscape. In doing so, I am also inspired by South Asian artists who have used fashion and other cultural components to express themselves. This is quite telling because our own sense of fashion as an expression is one of the first aspects that we let go of when we assimilate within the dominant hegemonic white culture (Aujla, 2000). As such, I capture my inspiration through collage by incorporating cultural elements such as South Asian textiles.

\section{Data Collection}

For this project, I sought to include a design that reflected a practice that participants engaged in everyday, as well as a method that was creative yet easy for participants to follow. As such, the data collection methods based on the methodology that I decided to use consisted of storytelling and collage. Below I have provided a brief description of both methods before explaining the process of the data collection. 


\section{Storytelling}

"Story is both art and quotidian, centripetal, and centrifugal, running deep and wide through the human psyche" (Lewis, 2011, p. 505). Researchers that advocate the use of this method emphasize storytelling as a universal form of human activity that we engage in our everyday lives and is common across all cultural traditions (Bell, 2012; Lewis, 2011).

Storytelling as an important human process reveals often hidden assumptions and beliefs about the story and the storyteller. Stories serve multiple useful functions in our lives. It provides a structure to the random experiences that we encounter. They also do not exist in vacuum, and as a vehicle of knowledge and tool of communication, reflexively stories shape individuals, groups, and society, and vice versa (Bell, 2002). As a form of narrative inquiry, storytelling reveals the storyteller's assumption that make up the story, regardless of whether they believe in the story or not (Bell, 2002). Moreover, it does not only reveal beliefs or narratives that the storyteller holds but it also reveals aspects of narratives that society holds to be true. Mumby (cited in Gubrium \& Holstein, 1998) argues that these dominant narratives or narratives that larger society holds to be true are powerful tools of social control. Therefore, marginalized groups as storytellers not only echo the dominant narratives of the society but they also pinpoint the subjugated narratives that are often masked by the dominant narratives.

In applying this knowledge of storytelling as a form of narrative inquiry, I aimed to look at the impact of the discourse of South Asian cultural violence on the participants by way of listening to the stories of violence against South Asian women that the participants have encountered. I also hoped to unpack these encounters by surfacing the dominant and subjugated narratives within participants' stories. 


\section{Collage}

As Burns (2003) notes: "Images enable meaning to travel in which words can't” (p. 9). Derived from the French verb coller, meaning to stick, collage is a process of sticking different materials, such as fabric, photographs, or paper on a flat surface, which comes together to form an image (Butler-Kisber \& Poldma, 2010). This practice of cutting and sticking is learned at an early age, thus, a form that is easy to follow even for a novice. Just as we give meaning to our random experiences via stories, collage reflects the vary way we experience the world by us presenting meaning to the relationship between different objects that we encounter (ButlerKisber, 2010).

In research, according to Butler-Kisber (2010), the growing interest in the use of collage as a form of arts-informed inquiry can be attributed to the way it allows researchers to be nonlinear and intuitive in their work. My preference of collage its capability to counter linearity in written text, while being able to impact different sense and say so much more at once. The process of putting together different pieces sparks new ways of knowing through sensory and embodied response. The result is new interpretations, connections, and meaning for both the creator and the viewer. Instead of being literal, collage is intrinsically 'metaphor and metonymy' which gives a sense of something, which challenges the "dichotomy of the intellect and the senses" (Butler-Kisber, 2012, p. 5). As a method of data collection, I have used collage making with the participants to conceptualize (Butler-Kisber, 2012) their identity. Creating a collage aimed to help participants to reflect their stories and identity in a different way, one that cannot be fully captured through verbal sharing of narratives. Collage also structures the findings. Unintentionally, the process of collage making facilitated my reflexivity as a researcher and assisted in development of themes. In this project, the final product of collage integrated multiple 
stories, including that of the researcher, and the meaning that I attached to the participants' responses.

\section{Procedure and Participants}

The study recruited participants between the age of $18-40$, first/second generation South Asian women, meaning they immigrated to Canada with their family at a younger age from one of the South Asian countries or were born in Canada to South Asian immigrant parents. Participants were recruited using purposeful sampling within my social network, specifically included those that either lived or near the region of Greater Toronto Area (GTA). I excluded those that had either recently immigrated to Canada or did not live majority of their life in Canada. Also, excluding men, anyone under the age of 18 or over 40 , those that did not live around GTA, and individuals outside of my social network. The recruitment process involved first sending a recruitment email (see appendix A), enclosed with a consent form (see appendix B). I connected with Interested individuals on the phone to explain the study. The final sample of participants consisted of two women, Asha and Sara (pseudonyms). Sara is a first-generation South Asian Canadian, she immigrated from India with her family during grade school. Asha is a second-generation South Asian Canadian, whose parents immigrated from India. Their age ranged from 25-35. Participants had different religious backgrounds.

\section{Focus group session}

Before the session began, the two participants were thanked for their time, were given $\$ 10$ gift card of their choice, and were compensated for their travel. They were provided with a list of community resources that they could access (see appendix C). The consent form was reviewed and gave an opportunity for participants to comment or ask questions regarding the project. The three-hour session was audio recorded. The focus group discussion was guided by 
the list of preliminary interview questions (see appendix D). The first session focused on participants' encounters with stories of violence against South Asian women. After hour and a half, we took a break, which was then followed by hour an half collage making. This last session also included discussion on their collage and ended with discussion on wellness. Refreshments and dinner were also provided.

\section{Data Analysis}

The audio recording file of participants' responses was transferred to a USB drive, which was then stored in a locked cabinet. The photos of the collages were taken, as well participants gave the collages for me to keep. The audio recording was then transcribed by me. The audio files were then deleted from the USB drive. The transcription file was saved and password protected on the USB drive and stored in a locked cabinet. Pseudonyms have been given to the participants.

Gibbs' (2012) Thematic analysis was used to analyze the responses of the participants. Here, I have outlined the steps of the analysis. I first read through the transcription, followed by making preliminary notes about the responses. After highlighting words, phrases, and anecdotes that stood out to me or had recurring patterns, these were given descriptions by using segment of raw data. Descriptions were turned into codes then categorized. To analyze the collage of the participants, I looked at the collage and the respective text from transcription side by side to develop codes. This followed the similar steps of description, coding, and categorization. I used Microsoft word to catalogue these codes and categories. Throughout the process, I kept a journal to reflect and memo the codes. The codes were continuously refined and moved around based on their relationship to one another to develop higher level categories until initial themes were defined. Once the initial themes were named, I began the process of making my collage. I went 
through a couple of versions of collage until creating the final product. The drafts of collages helped me to further reflect and ultimately use an image to bring together the different pieces of collage and themes together in a harmonized way. 


\section{CHAPTER 4. FINDINGS AND DISCUSSION}

The structure of the findings is based on the collage (see appendix E). To organize the findings and collage, I selected the image of Laxmibai, the queen of Jhansi, who led the 1857 rebellion against British (Feminism in India, 2017). She is an iconic South Asian woman warrior. In this collage, I use her image to represent the contemporary warriorhood of South Asian women. I also acknowledge the image Jhalkari Bai, a legendary Dalit Warrior whose story often gets subjugated due to her caste. Jhalkari Bai fought alongside and disguised herself as

Laxmibai, so that the Queen could escape safely (Feminism in India, 2017). The collage represents the experiences that the participants of this research have encountered in relation to South Asian cultural violence, its impact, and the ways in which they continue to take ownership to thrive despite the ongoing bombardment of the discourse. The backdrop of building with eyes through the windows represents contemporary time.

The themes of the findings correspond to the layers of the collage. The theme of making sense of collective experiences through weaving and layering corresponds to the technique of weaving and layering diverse fabrics to make up the collage. This theme is followed by the theme of treading a tightrope as first/second generation South Asian Canadian women, which is illustrated through tied first layer of the collage. Finally, the last theme of the everyday warriorhood of first/second generation South Asian Canadian women is depicted by the full image of Laxmibai in her armour and outfit.

\section{Weaving and Layering of Our Collective Experiences}

The theme of weaving and layering of our collective experiences establishes the context and history of participants' encounters with the stories of violence against South Asian women. It shows how participants have made sense of experiences that are marked by subtle and overt 
narratives of violence against South Asian women and its impact on them while growing up. The theme consists of understanding ourselves relative to others; childhood experiences and dreading the potential of violence; as well as self-preservation and internalizing narratives.

The theme corresponds to the technique of weaving and layering of different fabrics that build the larger collage. Most of the fabric is from my mother's saris owned which was symbolic in positioning myself in the collage. Like participants, my earliest memory of hearing a story of a violence against women was near my mother. Collectively, this experience involved our mothers hearing a story from someone in the family or the community, and we were the observer of this interaction. This set the stage for our understanding of violence against women in South Asian communities for years to come.

The technique of layering represents the parts of our socialization and the narratives that we internalized through a variety of sources. The layers also represent our own self-preservation. The technique of weaving illustrates connections and relations. Regardless of our experiences within our families or communities, encountering the stories of violence in these settings has helped us to makes sense of our personal experiences relative to those of others.

\section{Understanding Ourselves in Relation to Others}

Participants' parents were the base for their understanding of the stories of violence against South Asian women. Participants recalled that they encountered the stories by overhearing their parents discussing an incident that happened in the community. As an observaer of such interaction, participants learned the perspectives of different players and incorporated their parents' rationalizations of the story. The responses affected the participants' understanding of subsequent encounters with the stories.

Asha: ...my parents were talking about...this girl in our community. And she was raped... So, instead of blaming it on the person who raped her, they [the parents of the girl] 
blamed the girl, they blamed the daughter. So, my parents had a huge argument about this because my mom was like "how can you blame her you know she is only 15, like she doesn't know what's happening, somebody took advantage of her" and things like that. And my dad was like "but you know, who told her to go to that person's house?"... I remember like even afterwards, the whole community talked about this "oh, why did you let your daughter out of the house and things like that." This was the judgment on the parents, right? The mother is trying best to protect her daughter, and things like that but that's how the culture, that's how our community thought, right?

This story contains a clash of views marked by different power dynamics. The dominant narrative of victim blaming by Asha's father and the community is juxtaposed with the alternative narrative of supporting the survivor by Asha's and the survivor's mothers. Participants explained that the dominant narrative was also reinforced by the inequitable positioning of women in their families, which at first, participants associated as being the norm.

Sara: you think it's normal. It's cause every South Asian household typically the man is in control or it's whatever the guys say, right? So, I just thought that was normal that the woman is...

Asha: Lower.

Exploring further, participants connected unequal positioning to the socio-political context of their families. For Asha, it was her parents' experience of being an immigrant that limited opportunities for her mother, making her father the sole provider of the family; therefore, it was the context of immigration that reproduced the positioning and the beliefs about gender roles.

Despite their current ability to surface complexities in understanding narratives underlying stories of violence against South Asian women, participants explained that growing up with the narrative of victim blaming stuck with them. It left an impact on their younger selves by believing that they would experience the same fate as the victims in the stories.

\section{Childhood Experiences and Dreading the Potential of Violence}

Age was one of the salient parts of the response in relation to participants' first encounters with stories of violence against South Asian women. Participants traced their earliest 
memory of encountering the story at an age of 9 and 10. The stories involved rape and intimate partner violence, which were difficult for them to grasp at that age. The repeated encounters with stories of violence in addition to the first-hand experience of violence aggregated the feeling that violence was unavoidable as a South Asian girl or woman.

Sara: it's a lot of exposure at a very...

Riti: young age.

Asha: Like, "oh my god I am afraid to get married, I am afraid to get raped. If I meet a man I am gonna get abused. If I move to a different country, I am gonna be isolated." Riti: And especially since you are already experiencing violence in your family then it's like, man I'm hearing...

Asha: Yeah, it's more like it repeats itself, right?

Riti: Yeah cuz you are like I am experiencing this and then I hear all these other stories. Asha: So, it must be normal.

The frequency of the stories and their context- violence in intimate partner relationships, families, and friendships- made participants feel that the escape from violence was not possible. This evoked a belief that violence against South Asian women and girls by South Asian men was "normal", which was combined with the societal expectation of marriage led participants to feel that violence was inescapable for their future self. Moreover, participants believed that they would receive a lack of support based on the reaction of others. This feeling of inescapability was evident in Sara's reflection of her first encounter with a story of violence.

Sara: ... I was maybe 10...I heard this story from my parents... a girl in our neighbourhood... got married to a guy, a South Asian man, lived in the States but came to marry in India... the girl ended up moving to the States... I one day remember asking about her and they said... he's bothering her, and I took that as... I don't know if it was violence, physical abuse but he wasn't letting her work and she couldn't go out of the house... the mother and father-in-law like put tight leash on her. And so, I just remember being very scared and never like wanting to get married and like this staying away. And apparently at the time they called it a love marriage and usually those are very fantasized. It was not an arranged marriage, so I guess the two had talked of marriage and had a lot of time to get to know each other. So that was even more surprising that it was a love marriage, yet she was having these issues... And, I think it when I followed up on that story he was like physically (R: abusing her?) yeah... I just assumed that leven if it was a love marriage it ends up being or that when I grow up I'm not gonna be able to 
do what I want do or that I am gonna be beaten for no reason even though I am moving away from my family...

Sara surfaced two narratives that tend to be common and fantasized by some South Asians, including the idea of love marriage and moving to the West. Both are believed to somehow decrease chances of violence. It was a myth that Sara also believed at an early age until her encounter with this story. She reasoned that neither love nor arrange marriage, nor moving to the West would enable a South Asian woman to escape violence. As a result, she comes to understand herself and other South Asian women as dependent; women who must fulfill the expectations of society by sacrificing their needs and wants even in the face of violence.

Moreover, participants also shared that their view of South Asian men changed after ongoing encounters with stories of violence against South Asian women perpetrated by South Asian men. Asha, for example, emphasizing the feeling of inescapability from violence, explained how this impacted her view of, and relationship with South Asian men.

Asha: That's if you date somebody outside your culture ... and honestly, I have never been attracted to a South Asian male because of this.

For Asha, the solution to escape violence was to choose a partner who was not a South Asian man. This impact of internalizing narratives about South Asian men echoes Roy’s (1996) love laws which dictate parameters around the quality of connection between South Asian men and women. Here, attraction and choices for intimate relationship becomes defined by dominant narratives. Contrastingly, this view was not shared by Sara, attributing it to being "exposed to positive cases where that [violence] hasn't happened."

\section{Self-Preservation and Internalizing Narratives}

This section focuses on the steps that participants took to protect themselves due to the internalized narratives about South Asian women and culture. The fear of potential violence was 
combined with the fear of judgment from the community. In recalling her first encounter with a story of violence, Asha discussed how she became hypervigilant of the community:

Asha: Oh, it made me feel like okay, I am not gonna go to any of my friends' house. I am not letting this happen to me. My sisters, they are 6-years-older than me so they were her age. They were like 15-16 years old. They are like okay well we're not gonna do anything, we're not gonna do anything bad, we're gonna listen to our parents and things like that. Because ultimately... we go to temple, my dad is a community leader.... so, can you imagine like we were thinking 'oh my god what are they saying about us'. If we step out of line and things like that like how is that gonna change us, right? And had we not even heard that story maybe our lives would have been different now. Right? But the judgment was just it was just so bad....it was just devastating to hear but at the same time, me and my sisters were like we can't be out of line you know because the community is gonna judge us.

She explained that there was a stark difference prior to this experience in terms of the view of herself and the community; after the incident, she becomes significantly aware of others' judgment of herself and the women in her family. Part of the increased awareness about community's judgment had to do with believing in narratives about victim blaming, which prompts internalization of the narratives that one can control the potential of violence.

Ultimately, participants felt that it was their self-responsibility to protect themselves. The belief about self-responsibility and fear of the community resulted in augmented self-monitoring, which included conforming to the expectation of the family and the community; for example: obeying parents, limiting social outings, "crossing legs," and "talking properly."

The long-term changes had to do with the amalgamation of the dominant white culture and the encounters with South Asian cultural violence. Participants felt that the narratives that they encountered and the pressure to assimilate into the dominant culture resulted in developing a negative relationship with their identity as South Asian woman and the culture. Participants did not passively internalize harmful narratives; instead, the language that they used in describing their experiences shows that their actions resulted from a sense of self-preservation. The 
scholarship also notes that assimilation and rejection of one's own culture is a form of selfpreservation or a coping mechanism utilized by racialized groups (Aujla, 2000).

\section{Treading tightrope as first/second generation South Asian Canadian women}

The first layer of the collage captures the second theme of treading the tight rope as first/second generation South Asian Canadian women. Treading the tight rope is not a new concept for the daughters of immigrant parents, Jiwani (2006) for example explains that walking a tightrope reflects "negotiating and navigating between the often competing demands their own communities and those imposed by the dominant society" (p. 67). These demands create boundary markers of who and how women and girls interact with, and ultimately it governs their ability "to walk freely between worlds rather than constantly having to negotiate the tight interstices between different cultural arenas and expectations" (Jiwani, 2006, p. 27). Specifically, this theme demonstrates the ways in which dominant narratives about South Asian women and culture gets communicated which creates the effect of treading on the tight rope. In the collage, it is represented by a plain piece of sari that is held together by pieces of strings. From this perspective, the only aspects that appear are the single fabric, string, and the eyes. Treading the tight rope is embodied by the two pieces of string. The strings also create a border around the eyes, signifying the subtheme boundaries of our understanding of South Asian culture; and the eyes signify the subtheme of gaze. The single piece of fabric captures the subtheme of single story.

\section{The Gaze}

Razack (1998) explains that the gaze is about "what do the eyes of the dominant group see when they encounter subordinate groups?" (p.16). Here, the subtheme of gaze establishes the ways in which participants felt exposed and judged in the eyes of non-south Asians, particularly 
white bodies, as well as in the eyes of other South Asians. Participants emphasized the way they experienced the white gaze. Asha felt insecure and exposed by others' judgment about herself as a South Asian woman because "in thinking that they could be right," that there was a knowledge about herself that she was not aware of but needed to know. Sara, on the other hand, expressed feeling demeaned, and that such a judgment made her feel that she was lesser than the gazer.

The gaze was also encountered by the participants on a daily basis marked by 'racist innuendos' or subtle forms of racism; examples included encounters in which participants were engaging in their day-to-day routines, such as taking a bus or working, and unsolicited comments were made toward them being South Asian woman. In one scenario, a white woman was shocked that the participant was wearing a tank top as a South Asian woman.

Asha: okay couple weeks ago I was at my store... and I was wearing a tank top like...low low-cut... [quotes a woman] "where is your shawl?" ... and I was like "my shawl?" I was like "my shawl's at home why?" And then she's like "oh but isn't it...kind of like cold?" And I'm like" it's 80 degrees outside" ...

This uninvited comment within the context speaks to the assumptions that this white woman makes about South Asian women and the culture. Moreover, when considering the comment regarding location of the shawl it points to policing a South Asian woman who does not fit into the dominant narrative. The gaze as a tool to monitor is also evident in participants' encounters with other South Asians. In relation to this, participants discussed the how South Asian communities and families tend to monitor and judge women and girls.

Interestingly participants surfaced merging of the two gazes, of white bodies and South Asians, within a context of social services organizations. This specifically had to with participants' ability to seek help.

Sara: There is this increased stigma toward South Asian women if there is violence. Well like, let's say they were experiencing violence and they decided to leave their husband or whoever. So, then I feel like if they were to get help they, there is increased stigma toward 
them... that maybe like it was their fault. Like they asked for it or they are choosing not to work toward it

Asha: Or they did something. They should have just kept going. Or been strong for the children, quote unquote.

Sara: Right, yeah like put their kids first....

Asha: The blame goes on the woman, yeah. Especially if you go to like... if you go to an

Indian organization ... then there is lots of judgement. Like, oh you couldn't do this for your husband, why didn't you just do this... things like that... if I went to... [South Asian] organization. And I felt the judgement strong there like even from the receptionist desk... because they come from the same communities so they can understand and what not but it was more, "oh well you married a white person", right? Like obviously, it's going to be different you should have married someone of your own culture and things like that. But these are the things that I felt that they were trying to say to me kind of thing.

This aspect of the gaze contradicts the literature on South Asian women and help seeking (Ahmad et al., 2004; Gilbert et al., 2004). These studies argue that it is the internalization of patriarchy from South Asian culture limits help seeking behaviour; instead, participants attributed the gaze that communicates stigma and victim blaming from service providers as a barrier in seeking helping.

Asha's encounter with South Asian service provider also points to monitoring of South Asian women that happens within social services. Furthermore, this encounter with the gaze of the service provider toward Asha for marrying a white man and seeking help for intimate partner violence was an echo of prior histories of colonial encounter (Kumsa, 2007). The encounter positions the South Asian service provider as a "anti-colonial nationalist" who sees Asha as a colonized Indian woman, who has been tainted by "Westernization" and has betrayed her own culture (Kumsa, 2007; Narayan, 1997). The monitoring and victim blaming of racialized immigrant women is not exclusionary to South Asian specific organization (Menjivar \& Salcido, 2002); but participants held such organizations to stricter standards and felt more comfortable in accessing a mainstream organization because they believed this was less judgmental about South Asian women, or at least judgment from this source was one that they were willing to put up 
with. This section on gaze has focused on the ways in which first/second generation women experience judgment and exposure at an interpersonal level, the next section considers impact of being defined by single story in the media.

\section{Being Defined by a Single Story}

The use a single piece of fabric in the collage represent the ways in which the single story about South Asian people and culture within the media impacts the lives of first/second generation South Asian Canadian women. Here, I am using Adichie's (2009) definition of the single story which generalizes or portrays people "as one thing as only one thing, over and over again" (Adichie, 2009). Applying this concept to the collage, the single piece of fabric represents the single story about us. It also demonstrates the erasure by dominant narrative of our diversity and complexities who we are as women, and reduces South Asian culture into patriarchy.

Media is a significant source in reproducing a single story about South Asian culture and people (Jiwani, 2006). Participants shared that they are not only bombarded by news stories that involved violence against South Asian women, these tend to be the dominant news stories that they encounter about South Asian women. Interestingly, participants associated stories in media about violence against South Asian women and South Asian cultural violence to specific types of violence, such as rape, acid attacks, and "honour killing". Participants also recollected the stories that received wide media coverage, such as the case of Jyoti Pandey and Aqsa Parvez.

Sara: Yeah or when the Delhi girl was raped multiple times or multiple men. Asha: or acid burnings, the hijab. Like even the girl who died few years ago her family killed her, it was an honour killing, by Applewood, you know she went to Applewood high school in Mississauga.

While these were not the first stories that they encountered in the media, participants explained that these stories were the ones that stuck with them either because of the sensationalization of these stories in the media or the responses it received from the public. In 
addition, participants reflected on the implication behind the coverage of these stories in media.

In recalling, the story of Jyoti Pandey Asha explains:

Asha: Pure sadness. It was like why are we still doing this. Why is this still happening? Riti: Was that the first time you encountered a story about violence against South Asian women in media or can you recall?

Asha: No, it wasn't. It was just I thought we came so far from this, you know? And here is this happening again, people are going to think badly about South Asians and stuff like that... like the country worked so hard to get away from this you know and now its nonstop and I remember like... so there is this magazine Logical India and after that story... happened... they would just non-stop report rapes and crimes against women and stuff like that. Whereas before this it was just regular...stories that are happening. You know I thought they came far from this. Right? And now these assholes... having these huge stories....

For Asha, the implication behind such coverage had to do with how this one story reflected upon the whole country, as well as South Asians as a whole. The sadness comes from not only that this happened but that as South Asians we become known for this, which contributes to the existing stigma towards South Asians. Related to this, participants shared that at an interpersonal level such a single story about South Asians is reinforced when these types of stories come out in the media. This comes in a form of increased offhand comments made by non-South Asians regarding violence, for example, "India is a rape capital of the world" or the "joke: how do they have over billion people, it must be because of rape."

Participants also reflected on what was erased from the media about South Asians. This single story about South Asian women in the media, according to the participants, is also reinforced by the lack of coverage on positive and diverse stories about us. Participants explained that instead the positive stories that they encounter about South Asia in the West, stories tend to be about white bodies from humanitarian groups going to South Asian countries to "help". 
For participants, this single story in media and off-hand comments of everyday interaction might not be directly about them but the feeling that they are personally being judged by the others still lingers. It is not just their country that is being judged, but also themselves, their families, and their communities that are held responsible for the actions of a few.

\section{Defining Culture through Belongingness}

This section shows participants' relationship with South Asian culture, which was connected to the experiences that they had within and outside their families and communities, both related and unrelated to South Asian cultural violence. Specifically, these experiences are influenced by the gaze and the single story.

Participants interchangeably used community and culture, which demonstrates how the participants made sense of culture and community in relation to themselves. This also emphasized the role of community in establishing their relationship with culture. Some of the characteristics that participants discussed about the community overlap with the characteristics that they believed about culture. For example, participants shared that they felt their communities were rigid, unchanging, traditional, and not modern in relation to the communities' responses towards violence against women or girls. The way participants perceived South Asian culture and communities echo Orientalist assumptions that "racialized communities of colour are tradition-bound and frozen in time, not to mention inherently violent" (Jiwani, 2006, p.24). Interestingly, participants defined themselves as "white washed" in relation to South Asian culture. They shared that the beliefs that they held to be true about their culture were established by the experiences they had in their respective communities- both South Asian and non-South Asian- and that led them to developing a negative relationship with South Asian culture while growing up. Specifically, for Asha this included the experiences she had with the 
peers in her community while growing up. She explained that not being able to speak any of the South Asian language that the community spoke often made her feel left out. The feeling of being an outsider was also reinforced because Asha felt that she was "rebellious" toward the community. Ultimately, she questioned her community's ability to accept her for who she was. Contrastingly, the experience that Sara identified as significant to her relationship with South Asian culture involved growing up in a white dominant area as an immigrant child, and therefore, being influenced by her white peers. She explained that immigrating to this area as a child, she had to learn to assimilate to be accepted by her peers and this process involved letting go of some ties with South Asian culture.

Participants also placed an importance on the acceptance and experiences of belongingness of other South Asian women that were not considered to be part of the larger South Asian community. Belongingness was also determined by encounters with different South Asian women. This gave participants a window into who was accepted by the community and who was left out, and defined boundaries for them in terms of what constitutes South Asian culture. Participants shared that they have had limited encounters in a context of a community with other South Asian women who did not typically follow the dominant narrative. As such, participants came to believe that either there lacked a diversity among South Asian women or that there is only one way of being a South Asian woman; one who was obedient, submissive, and followed the expectations of her gender. Furthermore, community and family reinforced these expectations by focusing on fulfilling the gender role, such as getting married and having children, while minimizing career goals of the participants. Participants saw this lack of support and validation for the choices that they made as the community's inability to be empowering towards women. 
Asha: I feel more empowered... But it's through mostly, like it's not from the culture, like it's from going out and experiencing other things and other living experiences and stuff like that's empowered me.

Riti: So, wait you don't associate your empowerment to the South Asian culture.

Asha: no, no....

Sara: I don't think South Asian community in general is very empowering. Asha: No.

Sara: I don't think I have ever met South Asian community to tell me to go pursue my dreams.

Asha: Exactly, exactly.

Sara: It's always like go get married or go to university yes... Go get married, go have kids, have a house. It never goes beyond that...It's not like getting married is not pursuing your dreams but...like questions never asked what you want to do. This is the timeline you follow.

Here, participants did not associate empowerment to either the culture or the community; instead, participants put emphasis on self-empowerment, meaning that their empowerment came from choosing to diverge than the expectations placed on them. Moreover, participants understood empowerment as an aspect that was contradictory to South Asian communities or culture. Importantly, they themselves as South Asian women did not define their own empowerment belonging to or stemming from South Asian community or culture. Participants did not see their own selves as belonging to the culture or community and contributing to the empowerment of themselves or others. Therefore, empowerment was viewed as existing outside of the culture and community.

Similarly, the image of an empowered South Asian woman was also perceived to be stemming from outside of the culture, and understood other South Asian women's empowerment because of going against the expectations of the community. While, the participants had limited encounters with who they considered to be empowered South Asian women, because they were usually not considered to be part of the community, still had a significant impact on the participants. Participants explained that these women who exemplified alternative ways of being a South Asian woman, put the participants at ease for not following the dominant ways of being 
and opened different possibilities for participants to be themselves as South Asian woman.

Whereas, participants' encounters with women and girls who were not outspoken were believed

to be because of influence of past trauma or the socialization.

Asha: You know I always kind of wonder I was like when I see like very rebellious Indian girls for me it makes me feel more empowered actually but when I see the timid girls I am just like oh my god she hasn't broken out of her shell. Let's do it for her.

Riti: ...judging other Indian women or other South Asian women do you tend to perceive them in certain ways if they don't exhibit personality that you have?

Asha: I think that's what it is. When they are not outspoken about their feelings or they kind of like sit to themselves and they are quiet and things like that. I find it like, I kinda don't want to approach them because.

Riti: what else do you think about that? Do you think like that's coming from somewhere else?

Asha: Yeah, of course, coming from like coming from the upbringing

Riti: like yeah cuz for me...I...jump to the conclusion that man she must have experienced abuse.

Asha: Exactly, exactly and that's how I think.

The split portrayal as a pattern is also evident in Asha's collage (see appendix F). It

exemplifies a split image about both South Asian women and culture; on one hand, there is the empowered woman who has "overcome the culture" and on the other is an oppressed woman who has fallen a victim to the culture. We also come to believe in the dominant narratives about our culture; in line with the South Asian cultural violence discourse that out culture is traditional, backwards, and oppressive towards women; whereas the dominant white culture is empowering of women, progressive, and modern. The split portrayal of South Asian women and culture is noted by Narayan (1997) in her discussion of the subjectification of Indian women within colonial history. Similarly, it is evident in the examination by Chowdhury (2013), Durham (2015), and Olwan (2013) of media in articulating stories of violence against South Asia women. Moreover, the split portrayal echoes Grewal's (2013) concept of "outsourcing patriarchy" in which participants come to believe that patriarchy exists in South Asian communities and culture but not in the hegemonic culture or white communities. Participants themselves reinforce their 
position as modern, free, enlightened South Asian women by their desire to change or to save the perceived victimized South Asian woman, an act that Grewal (1996) explains, is a "reenactment" of the imperial relations that positioned English feminists as superior to colonized women.

\section{Warriorhood of First/Second Generation South Asian Canadian Women}

The theme that corresponds to the collage is an image of Laxmibai hidden in the second layer, it not visible until the threads of the first layer are removed (see appendix E). The process of opening the second layer symbolizes letting go of treading the tightropes of being first/second generation South Asian Canadian women. Here, Laxmibai is depicted with her armour and adorned in South Asian textiles representing the everyday warriorhood of first/second generation South Asian Canadian Women. This warriorhood involves being who we are even in the face of constant bombardment of harmful dominant narratives about ourselves. It is also about challenging these dominant narratives with our sword of creativity and defending ourselves from the narratives with our shield of resistance. Being South Asian women is not only about surviving but also thriving and celebrating who we are; celebrating our complexities, multiplicity, as well as our ordinary and dynamic selves which is symbolized by Laxmibai's clothing.

\section{Challenging Creatively and Daily Resistance}

This subtheme challenges the notion of South Asian women as submissive or powerless. It shows various ways that they challenge the everyday encounter with South Asian cultural violence. Resisting and challenging harmful dominant narratives first starts with themselves, which involves balancing multiple truths and realities. 
Participants reflected the struggle of upholding multiple truths without diminishing or oversimplifying the experiences of violence experienced by South Asian women. This struggle is also noted in the literature (Narayan, 1997; Razack, 1998; Jiwani, 2006), it speaks to the risk of aggravating racism toward both the men and the women in our communities, while being viewed by our communities as traitors and being seen by white society as women who abandoned their communities and culture because they are patriarchal (Razack, 1998). As such, holding multiple truths was deemed essential by the participants in making sense of the violence experienced by South Asian women. Doing so facilitated participants' understanding that they can both support survivors, and hold the structures and perpetrators responsible for the violence, without following the logic of South Asian cultural violence.

Participants also utilized a range of other ways to directly challenge others who reinforced South Asian cultural violence. Challenging others consisted of being strategic and creative. An example involved a white woman policing Asha's choice in clothing, briefly alluded to earlier. Here, Asha used humour to make the other woman aware of her problematic views and actions:

Asha: And they backtracked like "isn't it cold" and I am like "are you cold you are in a jeans and a t-shirt" and I knew where she was going but I was like let's humiliate the crap out of this lady because she is trying to do it to me right?! Then she was like "well women in your culture don't wear sleeveless tops" ... I was like "oh women in my culture, and I was like" oh, what culture is that?" And I am like "what culture are you from?" And she was saying that she was Italian. "oh, women in your culture should not be leaving the house and make that spaghetti sauce, right?!" And she was just she was so offended, like she was like [imitates gasp] and I was like "no, but seriously like in August don't you guys collect all of your tomatoes, and all BBQ, and family festival, and you have these barrels, and you clean your feet and go in, and stomp-stomp-stomp, " I was like "hold on is that pasta sauce or is that wine, I am not sure maybe you can emphasize on that because that's your culture."

Asha in this instance does not attempt to defend herself by educating the woman about South Asian culture or directly pointing out flaws in the logic. Instead, Asha's tactic was to 
surface the single story about women's role in the other woman's culture, not to reinforce a stereotype but to juxtapose single stories about both cultures. While we might not know if the other woman gained any sort of knowledge from this encounter, based on the reaction, Asha was able to make the woman realize the ridiculousness of playing on the single story.

Participants' resistance also manifests in forms of rebelliousness. While both participants expressed that they make choices that often do not conform to the expectations of South Asian culture or the white dominant culture, Asha specifically names this as her rebelliousness. Asha explains that her desire to be rebellious is (re)produced when she encounters the gaze or the single story about who a South Asian woman is supposed to be.

\section{Resist by Being}

Resistance is also understood by participants as not only about taking an action but also about just being. This aspect of being who participants are as first/second generation South Asian Canadian women speaks to the ways in which they embody or express their identity. Participants' mere expressions of themselves as complex, fluid, ordinary, and connected individuals is a challenge to the single story about themselves. The gaze may see what it wants to see but it does not erase participants' knowledge about themselves or their identities.

The complexities of participants as first/second generation South Asian Canadian women are evident throughout the interview. The complexities show up in different forms, such as contradictions about themselves, the culture, or response to their encounters with South Asian cultural violence. However, these contradictions were not taken up as uncomfortable or problematic, instead the participants embraced them to uphold multiple truths about themselves, their culture, and other South Asians. Moreover, the complexities of their identity were further 
captured in seeing themselves as being multifaceted, which is best illustrated by their collages (see Appendix F for participant collages).

Sara: S: thinking of my personality I guess or how like spend majority of my time like what does the daily day look like for me. Or how others perceive me maybe...well on my canvas I put on half brown paint to represent my Brown descent I guess or south Asian descent, and then with other things like heart, and a cross, some butterflies, and piece of fabric. I represented my faith, changes in life through butterflies, my profession, my love for Indian clothes, or Indian fashion I should say, and put some sunrays to represent my personality....

Riti: so, you are representing...

Sara: everything

Riti: so, it's more like your individual self

Sara: self. Yeah-yeah.

Here, Sara emphasizes her individual self; her personality, profession, faith, heritage, and her likes. By revealing aspects about their individual selves, participants demonstrated the diversity that often gets minimized by the single story about South Asian women. In addition, this shows that being first/second generation South Asian Canadian women does not have to look a certain way. As Sara shows through her collage that to her being this identity to her means all aspects of herself. In other words, being South Asian Canadian woman is not just limited to an act of engaging in culture directly, such as Indian fashion, but it can also be many other entities, such as one's faith. Moreover, weighing in her day-to-day life speaks to the ordinary and mundane aspects of being first/second generation South Asian Canadian women, which is just as complex and important to the participants in understanding themselves.

Moreover, the individual self simultaneously coexists with a relational self. Throughout the interview, participants continuously spoke about themselves and their experiences relative to other South Asians; or defined themselves within a context of a collective experience. This aspect is discussed in the section making sense of collective experience. This relational self was 
essential to their understanding as well as relating to their individual South Asian self. Here,

Asha wonderfully captures the importance of her identity and relationship with her parents.

Asha: I am a proud of being South Asian. Yes, because the thing is that I can't be fully recognized as being Canadian, right?! my parents already think...I am a bit because my parents are but I can't relate to that just the way I am I can't relate to a lot of Indian things ....

Riti: But you are still proud

Asha: I am still proud because my parents are... because I guess I love my parents and they would be happy if I was happy to be Indian, so yeah.

Questioning the acceptance and belongingness in the Canadian imagination is one that is

shared by the participants of Rajiva's (2006) and Aujla's (2000) study. Never having to belong in the national imaginary for First/second generation South Asian women like other racialized women is a result of being seen as the "perpetual outsiders" (Razack, Smith, Thobani, 2010, p.6). However, in Asha's case the relational self buffers lack of belonging in both the diasporic and motherland. As such, it is the bonds with parents that enables Asha to have a positive relationship with her identity as a South Asian Indian.

\section{Re-Establishing Positive Relationship with Culture}

The progression of the interview reveals a story about participants' journey of their relationship with the South Asian culture. It begins with the multiple encounters they have had with South Asian cultural violence in their childhood and teenage years that led them to developing a negative relationship with the culture. The earlier journey is also marked by assimilation and loss of some aspects of themselves that had to with the culture. This is evident in Sara's immigration experience.

Sara: ... well when I first moved to Canada-it's different cause you were born here right? but I'd say first year is basically take away everything you learned and learn new things... Or not relearn but learn the culture here like learn to communicate forget everything you learned back then. And now that I have associated myself oh I am more with being Canadian, not Indian and now that I am older I am trying to be both. 
Both participants defined being first/second generation South Asian Canadian as a hybrid identity, one in which they merge aspects of being Canadian and being South Asian. As it is evident in Sara's story, the hybridity in adulthood is a shift from the participants' earlier version of themselves embracing only one aspect of their identity. The story about first/second generation South Asian Canadian women, thus, evolves into a story of taking ownership of reconstructing our own narratives about South Asian Canadian women and to re-establishing a positive relationship with our culture.

Asha: ... I find that in my thirties now I am chasing down that culture, like I want to be part of that culture....

Riti: Why is that now that we are getting older we feel?

Asha: Cuz we appreciate it more

Sara: yeah you appreciate it more.

Like previous studies (Rajiva, 2006; Aujla, 2000) Participants explained that age was salient in developing their relationship with the culture; adulthood was thus marked by certain appreciation for the culture and desire to be an active part of it. Participants explained that taking ownership in reconstructing relationship to our culture looks very simple, yet it has an impact on their well-being. Part of this includes relearning or reconnecting with some of aspects of culture that they had given up, for example, cooking and eating South Asian food.

Participants also expressed the desire to engage in the culture in more direct ways, such as sending their children to cultural programs or planning a trip to go to South Asia. Their choice to engage in the culture in these ways, either big or small, reveals participants' longing to be part of the culture, but being active and intentional about the process. Furthermore, taking ownership of rebuilding a positive relationship with the culture was also important to the participants because it ensured preservation of the culture. Therefore, their positive relation to the culture had the potential of passing it on to future generation of South Asians. Their desire to preserve the 
culture and to pass it on to the future generation speaks to the value and the investment that they placed in South Asian culture. 


\section{CHAPTER 5. CONCLUSION: IMPLICATIONS, STRENTGHS \& LIMITATIONS}

This study attempted to demonstrate how as first/second generation South Asian Canadian women our lives are pierced with the discourse of South Asian cultural violence. Within the Canadian context, bodies of young South Asian women are used in marking boundaries of belongingness, immigration, and citizenship (Thobani, 2007). By including participants who are first/second generation South Asian Canadian, I aimed to show how the discourse operated and impacted their lives. Findings suggest that the discourse has had an impact on their relationship to themselves, other South Asians, and to South Asian culture. However, participants are not passive recipient of the discourse; as such, in their day-to-day lives participants challenge and resist, and simultaneously re-build their relationship with their culture.

This discourse that portrays South Asian women as victims of violent South Asian men and their patriarchal culture exists in the form of stories of violence against South Asian women. Participants of this study from a very young age have had an ongoing encounter with these stories in which they came to understand themselves and other South Asians within a context of the discourse of South Asian cultural violence. The frequency and sources of encounters surfaced fears that they themselves would one day be victim to the violence because violence was "normal" and "inescapable" for South Asian women. Their encounters were also marked by the ways in which South Asian women are defined and looked at by both South Asians and nonSouth Asians, especially white bodies. This experience was combined with feeling alienated from their respective communities, both South Asian and non-South Asian, which primes participants to understand themselves, their community, and their culture in narrow and contradictory ways. Marked by pressure to assimilate, their younger selves developed a negative relationship with the South Asian culture. However, participants getting older, begin to re-write 
their own stories in relation to their culture, as well as challenge themselves and others about narrows ways that South Asian women and culture are portrayed.

The strength of this study lies in arts-informed narrative methodology that captured complexities and diversities in which first/second generation express themselves.

Simultaneously, complexities and diversities challenge South Asian cultural discourse that often reduces these identities by labeling them as submissive and controlled by violent South Asian men and their patriarchal culture. The final collage that structured and represented the findings not only surfaced richness of descriptions but it can also work to make the knowledge of this study more accessible.

There were also some limitations in constructing the collage. First, participants expressed that they felt overwhelmed by the array of options in selecting materials for their collage. I also did not include found images for participants collage because I did not want participants to be influenced by the images. At the same time, an argument can be made that the materials used in making the collage inevitably influenced the ways in which participants responded to the discussion.

I hope that this study sparks increased interest in studies that challenge South Asian cultural violence by continuing to critically analyze the media but also creatively including voices of those that are impacted by it. Specifically, future research should consider narrowing down sources and geopolitical spaces of stories of violence against South Asian women, such as western news media or local news media, then look at their impact on South Asian women.

Another limitation of the study is its lack of inclusion for diversity between the participants. The participants varied in their generation status, regions of India, families' immigration experience, and their context of their communities, however due to time and 
feasibility, the study only included two participants and both were South Asian Indian. Future studies could include a greater diversity of participants.

Discussing gender and sexuality in a binary form is another limitation of this study. Acknowledging that the system of gender and sexuality, specifically the heterosexist binary gender-system, was imposed on the colonized through colonialism (Lugones, 2008); gender and heterosexuality themselves are colonial concepts and continue to penetrate our daily lives through coloniality of power (Lugones, 2007). Based on this theoretical knowledge, using a gender-binary as the foundation of this study is problematic because it in-turn reinforces the systems that were imposed on us; that is, using the same logic to understand and/or address the issue that created the problem in the first place. Moreover, the focus on gender binary and heterosexuality excluded the experiences of those that do not fit into these identities, which further erases and marginalizes the experiences of gender and sexually variant communities. Future research, therefore, should consider incorporating queer theories and LGBTTQIA+ participants in understanding the impact of South Asian cultural violence.

In terms of implications for social work practice, workers and organizations need to problematize the ways in which they themselves reinforce the discourse of South Asian cultural violence. Working alongside the South Asian community, we as social workers need to challenge and complicate the discourse of South Asian cultural violence within and outside of the community. The challenge also begins with ourselves. We need to be critically reflexive on our own internalized narratives related to South Asian cultural discourse, which shows up in forms of monitoring, judging, and reducing South Asian women into a single story.

Furthermore, as the findings suggest, relating to self as South Asian is connected to relating to the South Asian culture and community. The encounters that first/second generation 
South Asian Canadian women come to understand or buy into are a false claim that to receive gender equality (Jiwani, 2006), they must assimilate and abandon South Asian culture because of how South Asian women are portrayed in relation to their culture, families, and communities. Internalization of the harmful narratives and assimilation is tied to "feelings of inferiority, negation, and self-haltered as well as distancing from one's community" (Jiwani, p. 67). Therefore, community practice should consider developing programs that challenge the discourse of South Asian cultural violence, at the same time focus on building positive relationship with the culture or community.

Looking at Laxmibai, we need to surface stories from our history, both local and global, about South Asians that challenge the narrative that South Asian women are victims to barbaric South Asian men and their patriarchal culture. We as South Asian women also need to continue to take ownership in rewriting our history and reconstructing narratives about ourselves and South Asian culture. Community practice and education should also focus on surfacing subjugated stories of South Asian women. This can also be embodied in individual practice, where accompanying South Asians means challenging the many ways discourse of South Asian cultural violence shows up in our lives.

I also share Lugones's (2008) vision of building solidarity between racialized people, regardless of gender, for mutual liberation. Within the context of this study, it takes a form of collaboration between social workers, artists, activists, and community members creating spaces for communities to reimagine our identities as South Asians, both at local and global levels. This would challenge and buffer the impact of the discourse of South Asian cultural violence.

Finally, engaging in mutual liberation and addressing ongoing colonialism is also not possible without solidarity with Indigenous peoples. Within the Canadian context racialized 
immigrants are used and compliant in furthering the white settler colonial project against Indigenous people (Thobani, 2007). Here, stories of violence against South Asian women are one of the ways in which the issues of violence against Indigenous women and communities are diverted. According to Tuck and Yang (2012), decolonization in settler colonialism "is intimately connected to anti-imperialism elsewhere" but not equivocal to other anti-colonial struggles because the settler colonialism "fuels imperialism all around the globe" (p. 35). As South Asians, we must not "race to innocence" (Louise \& Razack, 1998) by masking our privilege and ridding ourselves of the oppression that we reinforce on Indigenous lands. We must hold ourselves accountable and be actively engaged in solidarity with Indigenous communities for "Indigenous sovereignty and futurity" (Tuck and Yang, 2012, p. 35). This same commitment must underlie our practice as social workers as we move forward to challenging oppression in all its forms. 


\title{
APPENDICES
}

\author{
APPENDIX A
}

RECRUITMENT EMAIL

Hello,

As you know I am a Master of Social Work student at Ryerson University's School of Social Work. I am currently completing a major research paper on the Stories of South Asian Cultural Violence and Its Impact on First/Second Generation South Asian Canadian Women, under the supervision of Dr. Samantha Wehbi, School of Social Work.

This study is designed to explore the experiences and perspectives of first/second generation South Asian Canadian Women about the representation of South Asian culture and stories of violence against South Asian women. Specifically, I am interested in looking at stories about South Asian culture and how it operates in the lives of South Asian Canadian women, and how they make sense of themselves as South Asian and their culture in relation to these stories.

I am seeking first or second generation South Asian Canadian women, between the ages of 1840, and living in or near Greater Toronto Area. First generation meaning, individuals that immigrated from South Asia with their parents or other family members at an early age. Second generation meaning, individuals who were born in Canada and have parents who immigrated from South Asia.

If you choose to participate in the study, then you will be invited to a focus group with two other participants that you might already know. You will be asked to share your experiences and make an individual collage. Specifically, you will be asked to share your experiences and perspective on representation of South Asian culture and violence against South Asian women. An example of this includes, a question regarding your first encounter with a story about violence in the South Asian community and your feelings towards that encounter.

The focus group will be approximately 180 minutes. The location will be decided after consulting all three participants about accessibility of the location. Incentive to participate in the study include \$10 gift card, I will have assortment of cards (e.g. coffee cards, book store, etc.) which you can select from at the start of the focus group. Refreshment will also be provided during the focus group and if needed you will be provided with 2 bus tokens or up to $\$ 15$ for parking if needed.

I acknowledge that we already have a standing relationship, however, your participation in this research study is strictly voluntary and there will be no penalties should you decline this offer or choose to withdraw from the study at any point. It will in no way impact our relationship. I appreciate your taking the time to read this and pass it on if you so choose.

I have attached the consent form with this email for you to review. 
If you are interested in the study, please contact me to arrange a phone call so we can review the consent form together.

This study has been approved by the Ryerson Research Ethics Board.

\section{Riti Dass}

riti.dass@ryerson.ca

(647) 894-2127

Thank you in advance for your time and consideration.

Sincerely,

Riti Dass 


\section{APPENDIX B}

\section{CONSENT FORM}

Dear participant,

You are being invited to participate in a research study. Please read this consent form so that you understand what your participation will involve. Before you consent to participate, please ask any questions to be sure you understand what your participation will involve.

The Stories of South Asian Cultural Violence and Its Impact on First/Second Generation South Asian Canadian Women

\section{INVESTIGATORS:}

This research study is being conducted by Riti Dass, supervised by Dr. Samantha Wehbi, from the School of Social Work, Faculty of Community Services at Ryerson University.

If you have any questions or concerns about the research, please feel free to contact Riti Dass at riti.dass@ryerson.ca or Samantha Wehbi at swehbi@,ryerson.ca.

\section{PURPOSE OF THE STUDY:}

This study is designed to explore the experiences and perspectives of first/second generation South Asian Canadian Women about the representation of South Asian culture and violence against South Asian women.

This study involves 3 first or second generation South Asian Canadian women, between the ages of 1840, and living in or near Greater Toronto Area. First generation meaning, individuals that immigrated from South Asia with their parents or other family members at an early age. Second generation meaning, individuals who were born in Canada and have parents who immigrated from South Asia.

This study is being conducted by a graduate student as a requirement for completion of their degree.

\section{WHAT YOU WILL BE ASKED TO DO:}

If you volunteer to participate in this study, you will be asked to do the following things:

- Attend a focus group session- expected to run for approximately 180 minutes. The session will be held at a private location that is most accessible to all participants.

- You will be asked to share your experience and perspective on representation of violence against South Asian women.

- As well as, share your experience and perspective on representation of South Asian culture as it relates to stories of violence against South Asian women.

- Specifically, I am looking at how the stories of South Asian cultural violence operates in the lives of South Asian Canadian women. As well as, how you make sense of yourselves as South Asian and the culture in relation to these stories.

- Some questions that you might be asked:

- When was the first time you heard a story about violence in our community? How did that make you feel as a South Asian woman? How did you see yourself and other South Asian women in relation to this?

- What do these stories make you think about South Asian culture? 
- You will then be asked to complete a collage, followed by a discussion about the collage focusing on some of the themes from the first part of the focus group.

- You will be provided with resources to make a collage (i.e. textiles, fabric, scissors, glue, fabric paint, etc.)

\section{POTENTIAL BENEFITS:}

Potential benefits include sharing personal and collective experiences that may contribute to the growing literature that challenges negative views about South Asian women and their culture. It may also give you an opportunity to explore and share what it means to be first/second generation South Asian woman with others. As well, making a collage may engage your creativity and a chance to explore representing yourself in a different way.

\section{WHAT ARE THE POTENTIAL RISKS TO YOU AS A PARTICIPANT:}

Participation in this study is low risk. However, because of the personal nature of the questions asked, you might reflect on unpleasant memories while responding to a question. You may experience discomfort when asked and answering questions in regards to stories of violence against South Asian women. For some, reflecting and sharing experiences and perspective on this may be difficult and may result in feeling upset and uncomfortable. Participants are reminded that they can take breaks, skip questions or stop participation, either temporarily or permanently. Resources in order to deal with stressful emotions will be provided at the beginning of the focus group.

There is also a social risk because of already standing relationship with the researcher and the other participants. While your participation in the study will not impact your relationship with the researcher, potential impact of your relationship with other participants is a social risk.

Maintaining confidentiality of other members is requested by all participants in the focus group, however, researcher cannot guarantee this on behalf of others.

Also, there is a potential for social risk if your identity is revealed. The steps taken to protect your privacy is discussed below.

\section{CONFIDENTIALITY:}

Researcher will take an extensive measure to protect your identity in this study. Pseudonyms (fake names) will be assigned to you. Other potential identifying information, for example the name of the community you belong to, will be omitted from the transcripts. Personal information including date of birth and address will not be recorded.

Information provided by you will only be viewed by the researcher and if necessary excerpts of transcripts with no identifying information will be shared with the supervisor. Information will not be accessible to any other parties.

The focus group dialogue will be audio recorded. Audio will be recorded on a password protected device and then transferred to a password protected computer. The audio file on the voice recorder will be deleted immediately after the transfer. Once transcribed the audio file on the computer will be deleted. Transcripts will be password protected and deleted one year after the completion of the research, in August 2018. Signed consent forms will be stored in a locked cabinet at researcher's house and will be shredded after one year of the research study has been completed. 
If you provide your consent (below) a photo of your collage that you make for the study will be included in the research paper, again the researcher will remove any personal identifiers.

\section{INCENTIVES FOR PARTICIPATION:}

Incentive to participate in the study include $\$ 10$ gift card of your choice; I will have an assortment of gift cards (e.g. coffee card, book store, etc.) for you to choose from at the start of the focus group. As well, refreshments will be provided during the focus group.

\section{COSTS TO PARTICIPATION:}

Reimbursement for bus fare and parking, may be provided at the request of the participant (up to two bus ticket/TTC tokens or $\$ 15$ for parking).

\section{VOLUNTARY PARTICIPATION AND WITHDRAWAL:}

Participation in this study is completely voluntary. You can choose whether to be in this study or not. If any question makes you uncomfortable, you can skip that question. You may stop participating at any time and you will still be given the incentives and reimbursements described above. While participants can withdraw participation at any_time, but you cannot withdraw discussion information provided up until the time of withdrawal. Your choice of whether or not to participate will not influence your future relations with Ryerson University or the investigators Riti Dass, or her supervisor, involved in the research.

\section{QUESTIONS ABOUT THE STUDY:}

Once you have completed reviewing this consent form on your own, please contact the research to review the consent form together and you can ask questions or clarify any information about participating in the study. If you have questions later about the research, you may contact:

\section{Riti Dass}

Researcher, MSW Candidate

riti.dass@ryerson.ca

\section{Samantha Wehbi}

Supervisor

swehbi@ryerson.ca

This study has been reviewed by the Ryerson University Research Ethics Board. If you have questions regarding your rights as a participant in this study, please contact:

Research Ethics Board

c/o Office of the Vice President, Research and Innovation

Ryerson University

350 Victoria Street 
Toronto, ON M5B 2K3

416-979-5042

rebchair@ryerson.ca

The Stories of South Asian Cultural Violence and Its Impact on First/Second Generation South Asian Canadian Women

\section{CONFIRMATION OF AGREEMENT:}

Your signature below indicates that you have read the information in this agreement and have had a chance to ask any questions you have about the study. Your signature also indicates that you agree to participate in the study and have been told that you can change your mind and withdraw your consent to participate at any time. You have been given a copy of this agreement.

You have been told that by signing this consent agreement you are not giving up any of your legal rights.

Name of Participant (please print)

Signature of Participant

Date

I agree to be audio recorded for the purposes of this study. I understand how these recordings will be stored and destroyed.

Signature of Participant Date

I agree not to share any information about other participants taking part in the focus group.

Signature of Participant

Date

I agree to share the collage I make for the purposes of this study. I understand that a photo of my collage will be included in the research paper.

Signature of Participant

Date 


\section{APPENDIX C}

RESOURCE LIST

*The information is taken from the agencies' websites. For more information, contact the agency directly or visit their website.

1) Ontario Mental Health Helpline: Provides information about mental health services in Ontario and support in your community. A helpful Information and Referral Specialist will answer your call, email or web chat $24 / 7$.

a. Contact Information:

P: 1(866) 531-2600

E: http://www.mentalhealthhelpline.ca/Home/Email

Live Chat: http://livechat.connexontario.ca/ECCChat/MHHchat.html W: http://www.mentalhealthhelpline.ca/

2) Canadian Mental Health Association- http://www.cmha.ca/get-involved/find-your-cmha/ Provides wide variety of mental health services including crisis support.

a. Contact Information:

\section{i. Durham Branch}

60 Bond St W, Oshawa, ON L1G, Canada

P: (905) 436-8760

F: (905) 436-1569

E: cmha@cmhadurham.org

W: http://cmhadurham.ca/

\section{ii. York Region Branch}

York Region Branch Main office 15150 Yonge Street, Suite 201 Aurora, ON, L4G 1M2

E: yorkregion@cmha-yr.on.ca

F: (905) 841-3007

P: (905)841-3977 Toll Free: 1(866)345-0183

W: http://www.cmha-yr.on.ca/

iii. Toronto Branch

P: East Office (east of Yonge Street)

(416) 789-7957 ext 3800 or e-mail: eastdecisionsupport@cmhato.org

P: West Office (west of Yonge Street)

(416) 789-7957 ext 3631 or e-mail: westdecisionsupport@cmhato.org

W: http://www.toronto.cmha.ca 


\section{iv. Peel Branch}

601-7700 Hurontario Street, Brampton, ON L6Y 4M3

E: info@,cmhapeel.ca

F: (905) 456-7492

P: (905) 451-2123; Crisis support Peel: (905) 278-9036; Duffering:

1(844)437-3247; Caledon: 1(888) 811-2222

W: http://www.cmhapeel.ca

\section{v. Halton Region Branch}

1540 Cornwall Road, Suite 102

Oakville, ON L6J 7W5

P: (905) 693-4270 or, Toll-free 1(877) 693-4270

F: (905) 693-9183

E: info@cmhahrb.ca

W: http://www.cmhahrb.ca

3) Telephone Helplines: (http://www.chs.ca/distress-centres-and-crisis-lines-ontario)

a. Toronto:

i. Assaulted Women's Helpline: For more than 25 years, the Assaulted Women's Helpline has served as a free, anonymous and confidential 24hour telephone and TTY crisis telephone line to all women in the province of Ontario who have experienced any form of abuse.

P: (416) 863-0511; Toll Free 1(866) 863-0511

W: http://www.awhl.org/

ii. Distress Centre: offers access to emotional support from the safety and security of the closest telephone. Callers can express their thoughts and feelings in confidence. Callers' issues can include problems related to domestic violence, social isolation, suicide, addictions, mental and physical health concerns. The Distress Centre offers emotional support, crisis intervention, suicide prevention and linkage to emergency help when necessary.

P: (416) 408-HELP (4357)

W: https://www.torontodistresscentre.com/about-us/contact-us

b. Peel:

i. Peel COAST (Crisis Outreach and Support Team): Mobile Crisis offers free support to individuals needing help in a mental health crisis, to their families, friends and caregivers. Provides immediate telephone support, prompt response by a mobile crisis team, pre-crisis and follow-up support and respite housing and hospitalization if needed. Mobile Crisis also offers linkages to mental health and community services as well as medical psychiatric back-up and hospital services. COAST Peel offers a response to non-emergency high risk mental health crisis consisting of a 
regulated mental health professional and a plain-clothed police officer specifically trained to deal with individuals experiencing a high risk mental health crisis.

P: (905) 278-9036

W: https://peel.cioc.ca/record/CMH0006

ii. Peel Distress Centre/Spectra Helpline: Distress Centre Peel provides free 24-hour telephone support, crisis intervention, and referral to other agencies where appropriate, for people in distress in Mississauga.

P: (905) 278-4890

W: http://www.spectrahelpline.org/

\section{c. Halton:}

i. COAST (Crisis Outreach and Support Team): will speak to you by phone to provide support and help you make a plan to stay safe. The mobile team of crisis professionals and specially trained plain clothes police officers may also visit you where you are to provide support and make a plan to keep you safe. May also provide ongoing telephone support and connect you to others who can help.

P: 1(877) 825-9011; Crisis line 24/7 - 1(844) 646-1700

W: http://halton.cmha.ca/what-we-do/get-help-and-stay-safe-in-a$\underline{\text { crisis/ }}$

ii. Distress Centre Oakville (can do text and online chat): Distress Centre Halton provides telephone and online support to people in our community to better cope with crisis, loneliness, and emotional stress.

Text to (647) 557-6250

Oakville P: (905) 849-4541; Burlington P: (905) 681-1488;

North Halton P: (905) 877-1211

W: http://www.dchalton.ca/

d. Durham:

i. Durham Mental Health Services (Crisis Response): Offers a range of crisis supports to assist individuals who are experiencing a personal or situational crisis. A community visit by the mobile crisis team can be arranged to support the individual in their preferred environment. Followup support, including linkage and referral to other community supports, are also available.

P: (905) 666-0483; Toll Free: 1(800) 742-1890

W: http://dmhs.ca/cause/crisis-response/

e. York Region: 
ii. COPE hotline (Community Crisis Respond Services): Individuals are connected with a crisis worker, 24 hours a day, 7 days a week. The crisis worker will provide an immediate telephone response in a variety of situations, such as if you are feeling depressed, distressed, lonely, anxious, scared, angry or are worried that you have no where to go.

P: 1(855) 310-COPE (2673) phone, or Toll Free: 1(866) 323-7785

W: http://www.yssn.ca/Crisis-Response-Services 


\section{APPENDIX D \\ INTERVIEW GUIDE}

\section{1) Participants will be asked questions related to following themes}

Have you heard about South Asian cultural violence? What do you think that means to you?

What are your thoughts on incidence of violence within South Asian culture? As in rate of violence in our culture?

- First time knowledge about violence against South Asian woman

- E.g. When was the first time you heard a story about violence in our community?

- How did that make you feel as south Asian, specifically you south Asian woman?

- Did that change your view about yourself? If so, how?

- How did you perceive other South Asians after that encounter?

- So now I want to think about specific stories about violence against South Asian women in media. For example, stories about honour violence.

- When was the first time you heard this story?

- What did you think about it?

- How did it make u feel as a South Asian woman?

- Representation of stories of South Asian women and their violence

- Do you think our society, specifically media, accurately portrays these stories and experiences of South Asian women?

○ Relationship to culture

- What do these stories make you think about our culture?

- How do these stories impact your relationship to the South Asian culture?

- Challenging the discourse

- What are your responses or reactions when someone outside of South Asian culture represents our culture as violence or oppressive toward women? How does it make you feel when they represent you or your culture this way?

- Can you tell me about a time when you challenged someone about these stories?

- Can you tell me about a time when you challenged the negative representation of yourself and culture?

- Do have anything would like to add that you haven't had chance to discuss yet? 


\section{2) Collage:}

- Participants will be asked to make a collage to represent themselves as first/second generation South Asian Canadian women.

- reflecting on their experiences related to the discourse and focus group discussion. As well reflect on how they create alternative identity.

- They will be given resources (e.g. fabric, glue, scissors, fabric paint, and canvas) to make the collage

○ The discussion on collage will focus on following types of questions:

- What did feel and think while making this collage?

- Tell me about your collage

- What textile and colour did you choose and why?

- How does this reflect your identity as first/second generation South Asian woman?

- How do you as a first/second generation South Asian woman challenge how you are represented within our society through this collage?

\section{$\bigcirc$ Ending the Session:}

- Making a collage is a form of self-care

- The participants will be invited to reflect on self-care activities to address emotional impacts of the discourse of South Asian women and culture

- What would you say are some strategies or activities that would be helpful?

- Self-expression and self-care

- Taking yourself is important especially after this long interview

- Do have anything would like to add that you haven't had chance to discuss yet?

- Okay we are ready to wrap.

- Do you have any further questions for me?

- Remind about the next process 
APPENDIX E

IMAGES OF THE COLLAGE

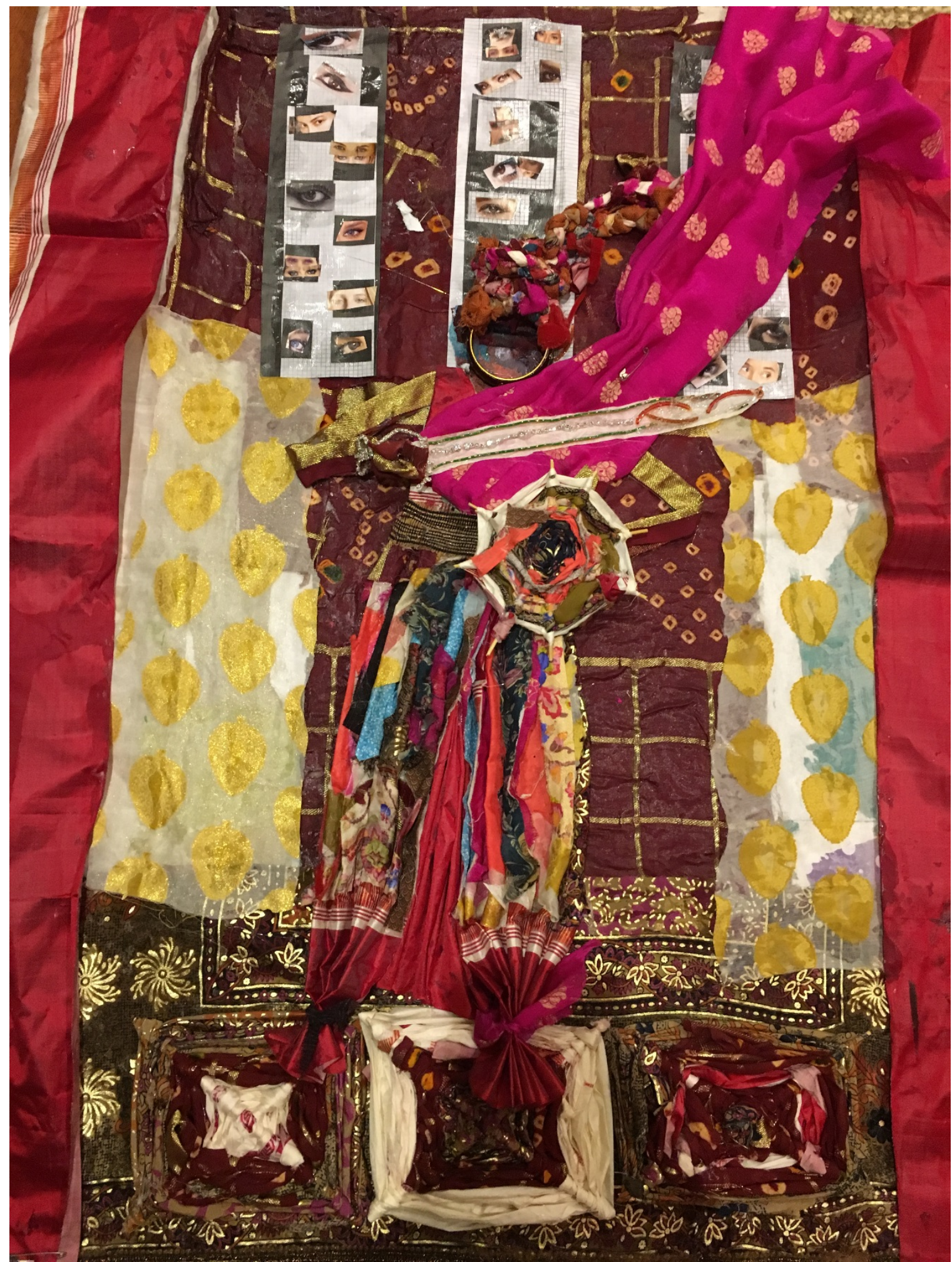


Collage with object showing scale

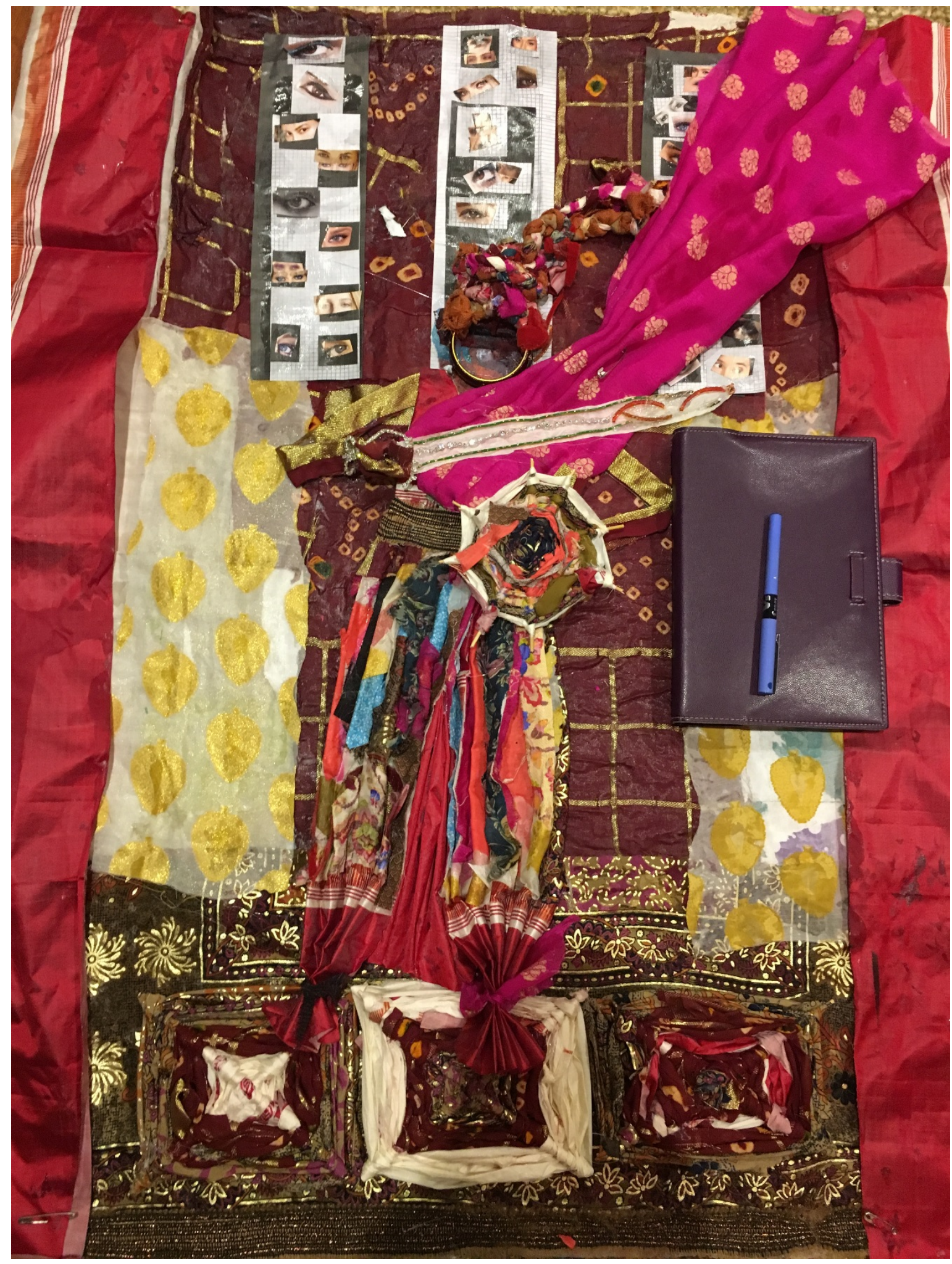


Collage Theme 1: Weaving and Layering of Our Collective Experiences
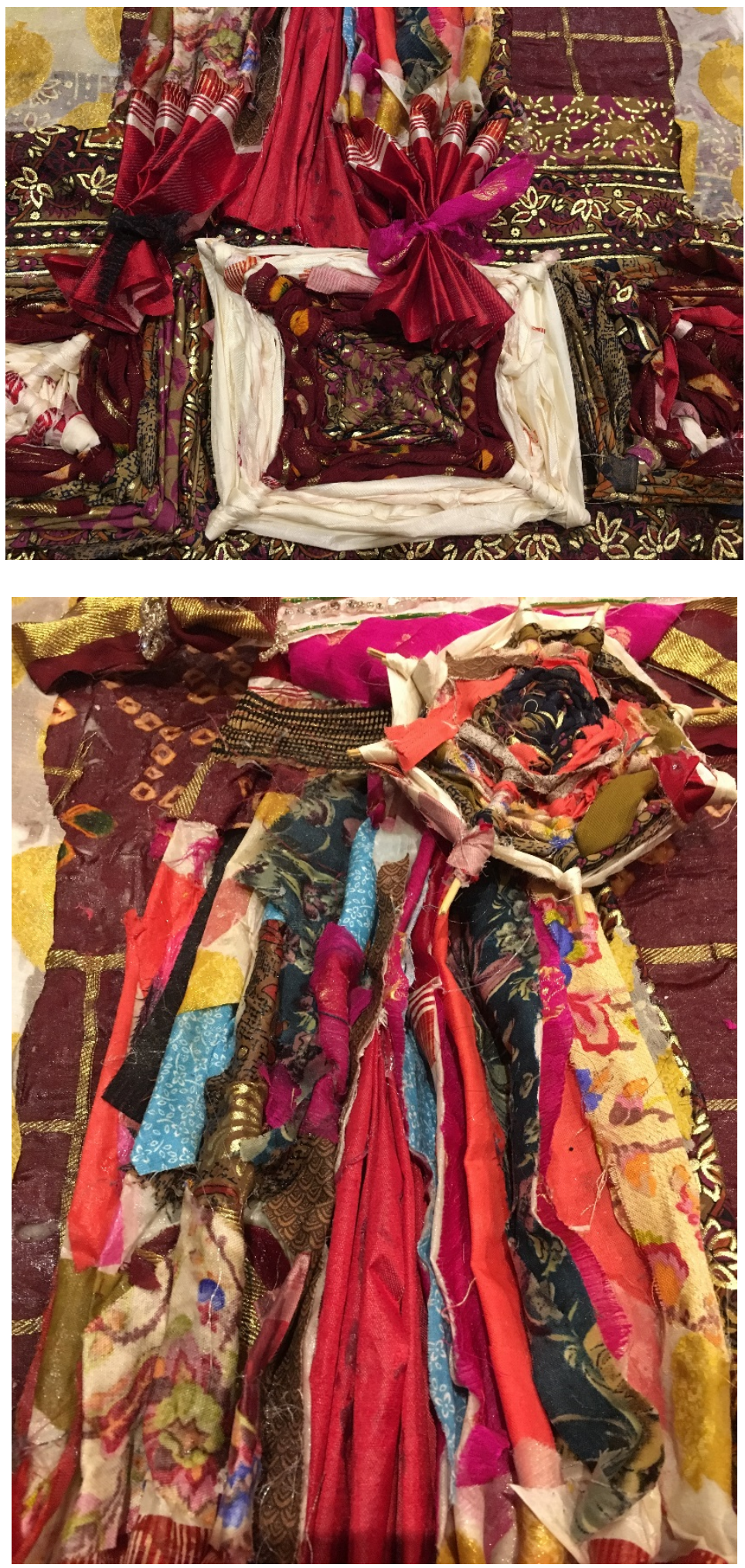
Collage Theme 2: Treading the Tight Rope as First/Second Generation South Asian Canadian

Women

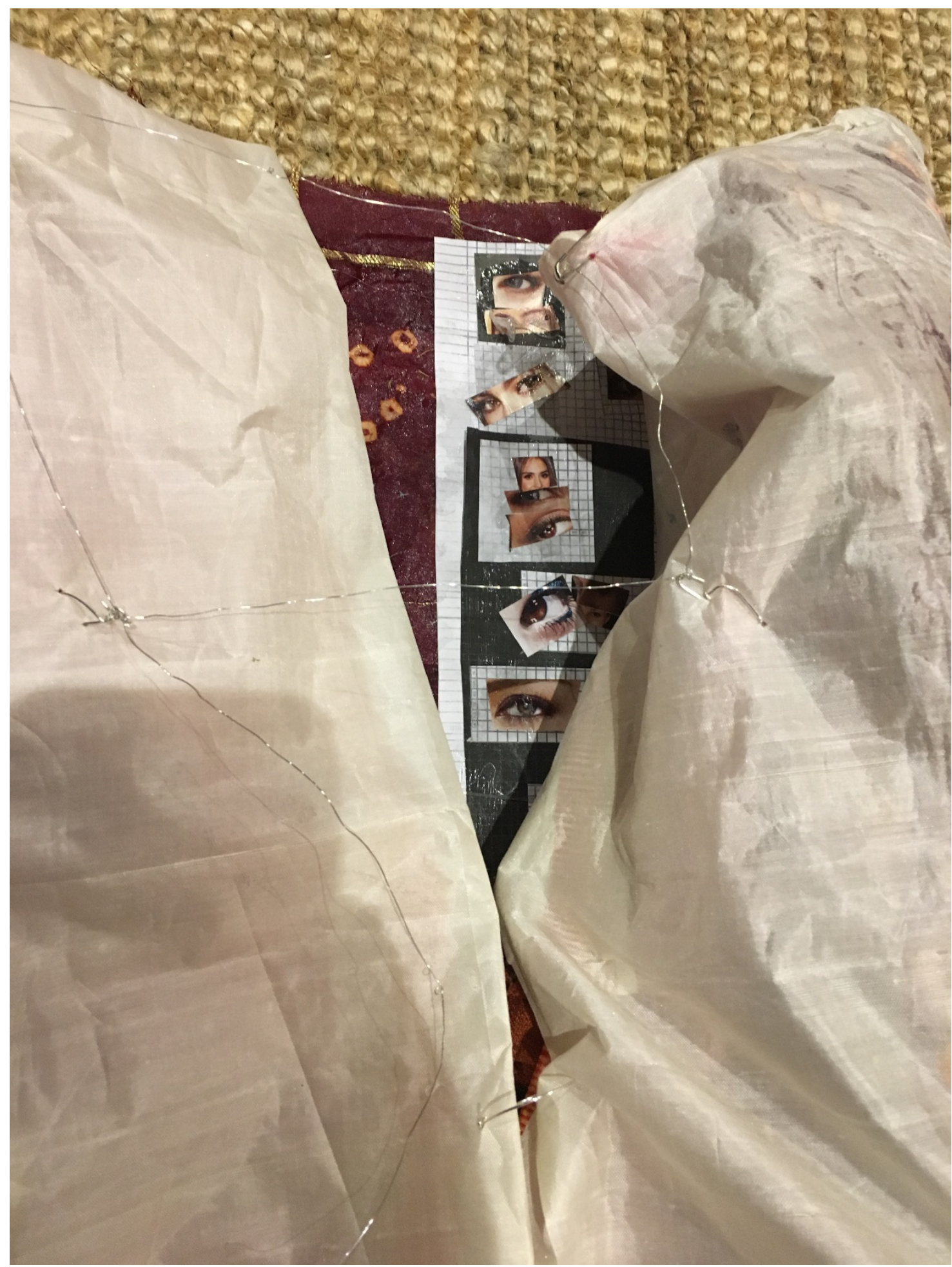


Collage Theme 3: Warriorhood of First/Second Generation South Asian Canadian Women

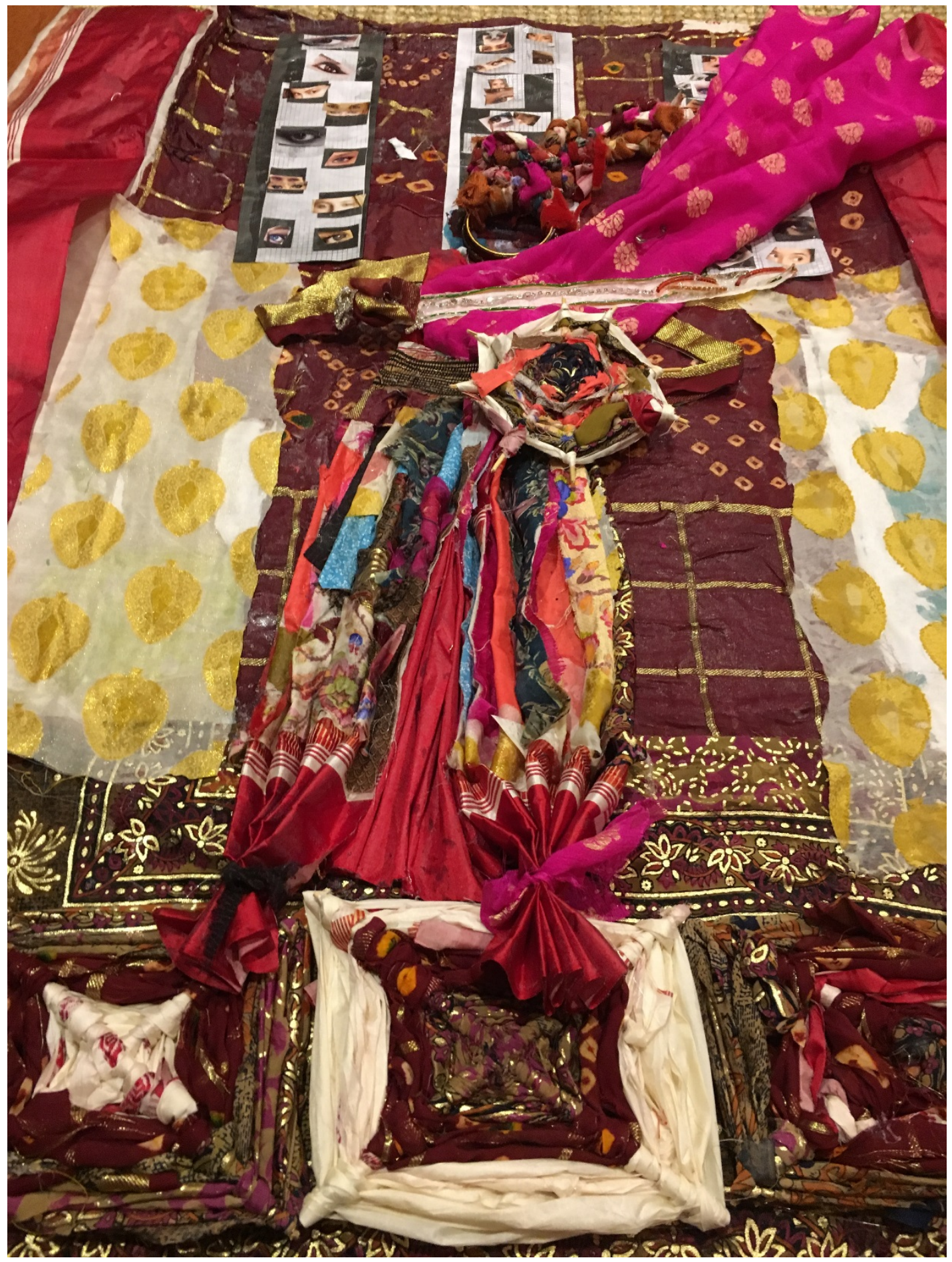


APPENDIX F

PARTICIPANTS' COLLAGES

Asha's Collage

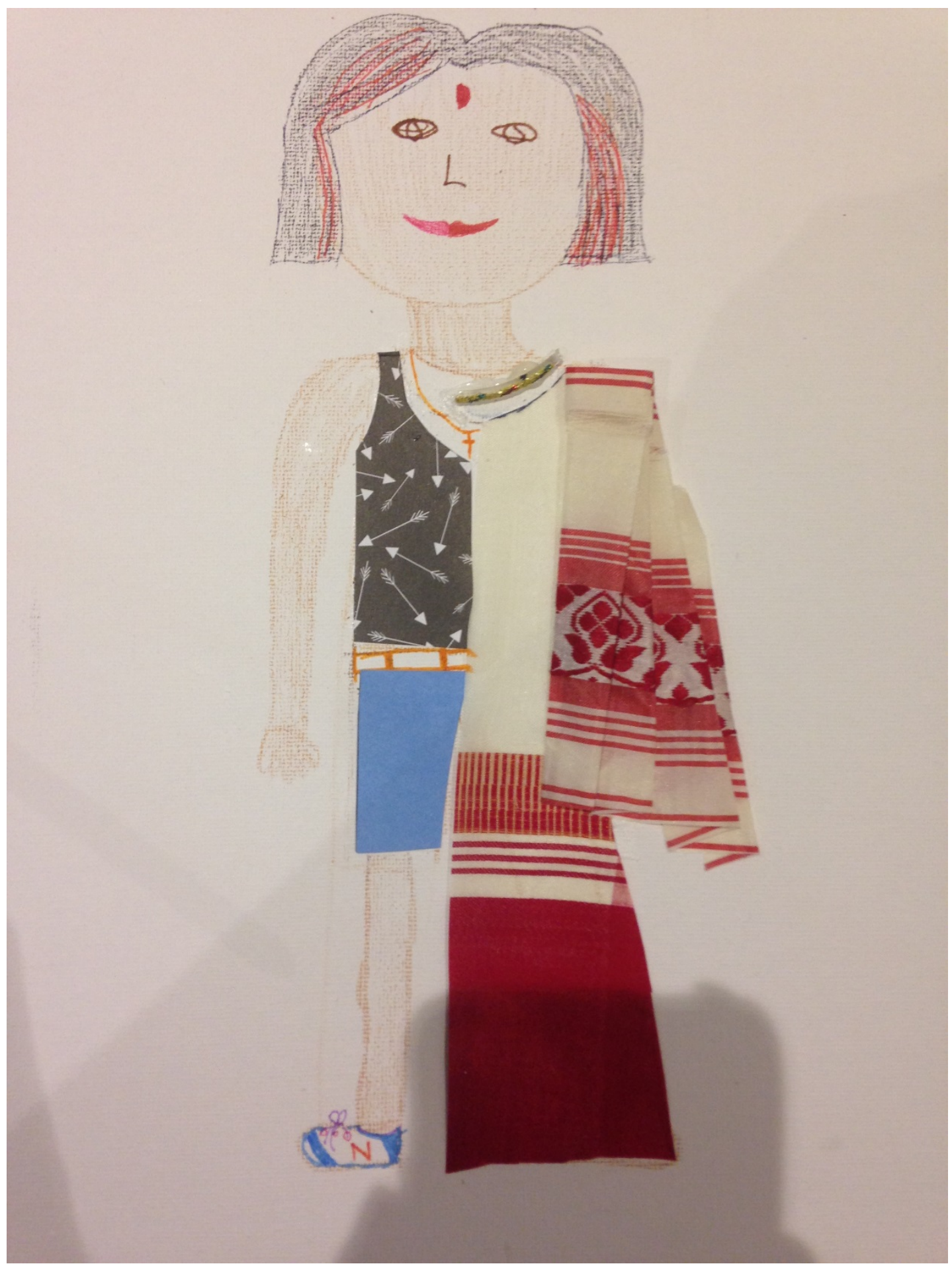


Sara's Collage

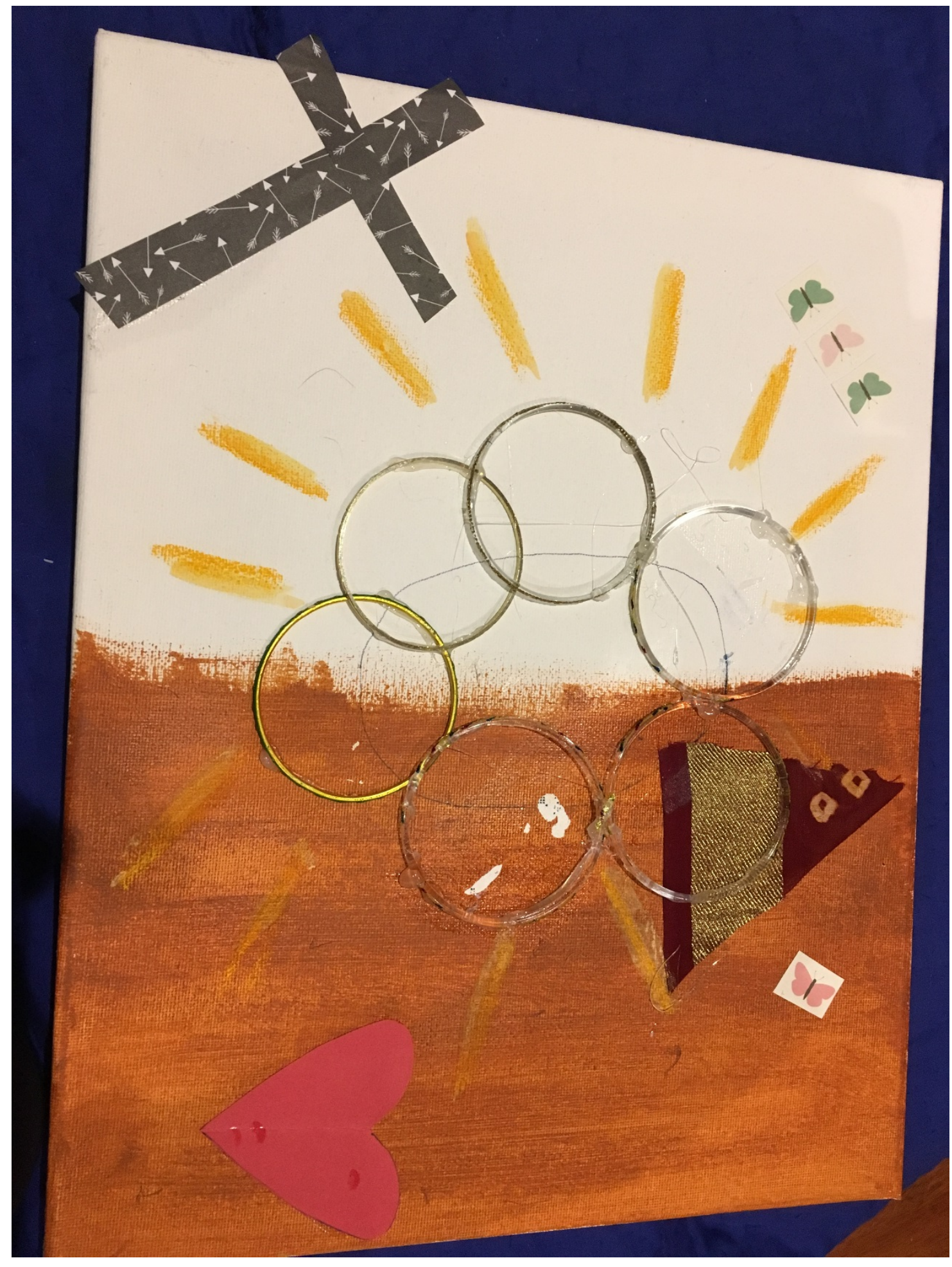




\section{$\begin{array}{ll}\text { Ryerson } & \text { Research } \\ \text { Ethics Board }\end{array}$}

To: Riti Dass

Faculty of Social Services/Social Work

Re: REB 2017-001: The Myth of South Asian Cultural Violence: Its Impact on First/Second

Generation South Asian Canadian Women.

Date: February 15, 2017

\section{Dear Riti Dass,}

The review of your protocol REB File REB 2017-001 is now complete. The project has been approved for a one year period. Please note that before proceeding with your project, compliance with other required University approvals/certifications, institutional requirements, or governmental authorizations may be required.

This approval may be extended after one year upon request. Please be advised that if the project is not renewed, approval will expire and no more research involving humans may take place. If this is a funded project, access to research funds may also be affected.

Please note that REB approval policies require that you adhere strictly to the protocol as last reviewed by the REB and that any modifications must be approved by the Board before they can be implemented. Adverse or unexpected events must be reported to the REB as soon as possible with an indication from the Principal Investigator as to how, in the view of the Principal Investigator, these events affect the continuation of the protocol.

Finally, if research subjects are in the care of a health facility, at a school, or other institution or community organization, it is the responsibility of the Principal Investigator to ensure that the ethical guidelines and approvals of those facilities or institutions are obtained and filed with the REB prior to the initiation of any research.

Please quote your REB file number (REB 2017-001) on future correspondence.

Congratulations and best of luck in conducting your research.<smiles>Cc1ccc(C)cc1</smiles>

Dr. Nancy Walton, $\mathrm{PhD}$

(A) Co-Chair

Ryerson Research Ethics Board

416-212-4952

nwalton@ryerson.ca

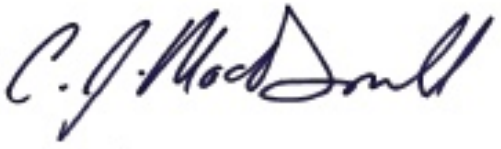

Dr. Chris Macdonald, $\mathrm{PhD}$

(A) Co-Chair

Ryerson Research Ethics Board

416-979-5000 ext. 6903

chris.macdonald@ryerson.ca 


\section{REFERENCE LIST}

Adichie, C. N. (2009, July). The Dangers of a Single Story [Video File]. Retrieved from https://www.ted.com/talks/chimamanda_adichie_the_danger_of_a_single_story?utm_ca mpaign=tedspread--a\&utm_medium=referral\&utm_source=tedcomshare

Ahmad, F., Riaz, S., Barata, P., \& Stewart, D. E. (2004). Patriarchal beliefs and perceptions of abuse among South Asian immigrant women. Violence Against Women, 10(3), 262-282.

Ahmed, B., Reavey, P., \& Majumdar, A. (2009). Constructions of 'Culture' in accounts of south Asian women survivors of sexual violence. Feminism \& Psychology, 19(1), 7-28.

Ahmed, S. (2000). Strange encounters: Embodied others in post-coloniality. New York: Routledge.

Aujla, A. (2000). Others in their own land: Second generation South Asian Canadian women, racism, and the persistence of colonial discourse. Canadian Woman Studies, 20(2), 41-47.

Beharry, P., \& Crozier, S. (2008). Using phenomenology to understand experiences of racism for second-generation South Asian women. Canadian Journal of Counselling, 42(4), 262277.

Bell, J. (2002). Narrative Inquiry: more than Just telling stories. TESOL Quarterly, 36(2), 207213.

Bhatt, A. P. (2008). The Sita syndrome: Examining the communicative aspects of domestic violence from a south Asian perspective. Journal of International Women's Studies, 9(3), $155-173$.

Blackwell, M., Briggs, L., \& Chiu, M. (2015). Transnational feminisms roundtable. Frontiers: A Journal of Women Studies, 36(3), 1-24. 
Butler-Kisber, L. (2008). Collage as inquiry. In Knowles, J. G. \& Cole, A. L. (Eds.) Handbook of the arts in qualitative research: Perspectives, methodologies, examples, and issues (pp. 265-277). Thousand Oaks: SAGE Publications Ltd. Retrieved from http://dx.doi.org/10.4135/9781452226545

Butler-Kisber, L., \& Poldma, T. (2010). The power of visual approaches in qualitative inquiry: The use of collage making and concept mapping in experiential research. Journal of Research Practice, 6(2), M18.

Chaudhuri, S., Morash, M., \& Yingling, J. (2014). Marriage migration, patriarchal bargains, and wife abuse: A study of South Asian women. Violence Against Women, 20(2), 141-161.

Chowdhury, E. H. (2015). Rethinking patriarchy, culture and masculinity: transnational narratives of gender violence and human rights advocacy. Journal of International Women's Studies, 16(2), 98-114.

Chowdhury, E. H., \& Philipose, L. (2016). Dissident friendships: Feminism, imperialism, and transnational solidarity. Chicago: University of Illinois Press.

de Carteret, P. (2008). Storytelling as research praxis, and conversations that enabled it to emerge. International Journal of Qualitative Studies in Education, 21(3), 235-249.

Devdas, N. R., \& Rubin, L. J. (2007). Rape myth acceptance among first- and second-generation South Asian American women. Sex Roles, 56(9), 701-705.

Fellows, M. L. \& Razack, S. (1998). The race to innocence: Confronting hierarchical relations among women. The Journal of Gender, Race \& Justice, 1(4), 335-555.

Feminism in India. (2017, November 22). Watch: Jhalkari Bai-the Dalit woman warrior of 1857 [Video File].

Retrieved from https://feminisminindia.com/2017/11/22/jhalkari-bai-dalit-video/ 
Gallagher, K. M. (2011). In search of a theoretical basis for storytelling in education research: Story as method. International Journal of Research \& Method in Education, 34(1), 4961.

Durham, M. G. (2015). Scene of the crime: News discourse of rape in India and the geopolitics of sexual assault. Feminist Media Studies, 15(2), 175-191.

Gibbs, G. (2007). Analyzing qualitative data. London: SAGE Publications, Ltd.

Gilbert, P., Gilbert, J., \& Sanghera, J. (2004). A focus group exploration of the impact of izzat, shame, subordination and entrapment on mental health and service use in South Asian women living in Derby. Mental Health, Religion \& Culture, 7(2), 109-130.

Grewal, I. (1996). Home and harem: Nation, gender, empire, and the cultures of travel. Durham: Duke University Press.

Grewal, I. (2013). Outsourcing patriarchy. International Feminist Journal of Politics, 15(1), 119.

Grosfoguel, R. (2011). Decolonizing Post-Colonial Studies and Paradigms of Political-Economy: Transmodernity, Decolonial Thinking, and Global Coloniality. Transmodernity: journal of Peripheral Cultural Production of the Luso-Hispanic World, 1(1). Retrieved from https://escholarship.org/uc/item/21k6t3fq

Gill, A. K., \& Brah, A. (2014). Interrogating cultural narratives about 'honour'- based violence. European Journal of Women's Studies, 21(1), 72-86.

Gubrium, J., \& Holstein, J. (1998). Narrative Practice and the coherence of personal stories. The Sociological Quarterly, 39(1), 163-187.

Hearne, B. (2002). Storytelling. In J. R. Schement (Ed.), Encyclopedia of Communication and Information (Vol. 3, pp. 969-973). New York: Macmillan Reference USA. Retrieved 
from

http://link.galegroup.com.ezproxy.lib.ryerson.ca/apps/doc/CX3402900265/GVRL?u=rpu main\&sid $=$ GVRL\&xid $=$ c9de304c

Jiwani, Y. (2006). Discourses of denial: Mediations of race, gender, and violence. Vancouver: UBC Press.

Kaplan, C., Alarcón, N., \& Moallem, M. (1999). Introduction: between woman and nation. In C. Kaplan, N. Alarcon, and M. Moallem (Eds.) Between woman and nation: Nationalisms, transnational feminisms, and the state (pp. 1-16). London: Duke University Press.

Kaplan, C., \& Grewal, I. (1999). Transnational feminist cultural studies: beyond the Marxism/poststructuralism/feminism divides. In C. Kaplan, N. Alarcon., \& M. Moallem, Between woman and nation: Nationalisms, transnational feminisms, and the state (pp. 349-363). London: Duke University Press.

Knowles, J. G., \& Cole, A. L. (2008). Handbook of the arts in qualitative research: Perspectives, methodologies, examples, and issues. Thousand Oaks: Sage Publications.

Koch, T. (1998). Story telling: Is it really research? Journal of Advanced Nursing, 28(6), 11821190.

Korteweg, A. C. (2014). 'Honour killing' in the immigration context: Multiculturalism and the racialization of violence against women. Politikon: South African Journal of Political Studies,41(2), 183-208.

Leavy, P. (2009). Method meets art: Arts-based research practice. New York: Guilford Press.

Lewis, P. J. (2011). Storytelling as research/research as storytelling. Qualitative Inquiry, 17(6), 
505-510.

Lugones, M. (2007). Heterosexualism and the colonial/modern gender system. Hypatia, 22(1), 186-209.

Lugones, M. (2008). Coloniality of gender. World \& Knowledges Otherwise, 1-17. Retrieved From https://globalstudies.trinity.duke.edu/wpcontent/themes/cgsh/materials/WKO/v2d2_Lugones.pdf

Maiter, S., Alaggia, R., \& Trocmé, N. (2004). Perceptions of child maltreatment by parents from the Indian subcontinent: Challenging myths about culturally based abusive parenting practices. Child Maltreatment, 9(3), 309-324.

Malhi, R. L., \& Boon, S. D. (2007). Discourses of "democratic racism" in the talk of South Asian Canadian women. Canadian Ethnic Studies, 39(3), 125-149.

Mason, R., Hyman, I., Berman, H., Guruge, S., Kanagaratnam, P., \& Manuel, L. (2008). Violence is an international language: Tamil women's perceptions of intimate partner violence. Violence Against Women, 14(12), 1397-1412.

Meetoo, V., \& Mirza, H. S. (2007). "There is nothing 'honourable' about honour killings": Gender, violence and the limits of multiculturalism. Women's Studies International Forum, 30(3), 187-200.

Menjívar, C., \& Salcido, O. (2002). Immigrant women and domestic violence: Common experiences in different countries. Gender and Society, 16(6), 898-920.

METRAC. (2015, May 7). Submission by METRAC: action on violence, to the house of commons standing committee on citizenship and immigration Re: BILL S-7. Retrieved from http://owjn.org/owjn_2009/images/pdfs/metrac-submission--commons-bill-s-7.pdf 
Narayan, U. (1997). Dislocating cultures: Identities, traditions, and third-world feminism. New York: Routledge.

Olwan, D. M. (2013). Gendered violence, cultural otherness, and honour crimes in canadian national logics. Canadian Journal of Sociology, 38(4), 533-555.

Patil, V., \& Purkayastha, B. (2015). Sexual violence, race and media (in)visibility: Intersectional complexities in a transnational frame. Societies, 5(3), 598-617.

Pascale, C.M. (2010). Epistemology and the politics of knowledge. Sociological Review, 58(s2), 154-165.

Quijano, A. (2000). Coloniality of power, eurocentrism, and Latin America. Nepantla: Views from South, 1(3), 533-580.

Rajiva, M. (2006). Brown girls, white worlds: Adolescence and the making of racialized selves. Canadian Review of Sociology/Revue Canadians De Sociologie, 43(2), 165-183.

Razack, S. (1998). Looking white people in the eye: Gender, race, and culture in courtrooms and Classrooms. Toronto: University of Toronto Press.

Razack, S., Smith, M. S., \& Thobani, S. (Eds.). (2010). States of race: Critical race feminism for the 21st century Between the Lines. Toronto: Between the Lines.

Roy, A. (1997). The god of small things ( $1^{\text {st }}$ ed.). Toronto: Vintage Canada.

Roychowdhury, P. (2013). "The Delhi gang rape": The making of international causes. Feminist Studies, 39(1), 282-292.

Saldivar, J. D. (2007). Unsettling race, coloniality, and caste: Anzaldua’s Borderlands/La Frontera, Martinez's Parrot in the Over, and Roy's The God of Small Things. Cultural Studies, 21(2-3), 339-367.

Shankar, J., Das, G., \& Atwal, S. (2013). Challenging cultural discourses and beliefs that 
perpetuate domestic violence in South Asian communities: A discourse analysis. Journal of International Women's Studies, 14(1), 248-262.

Shier, A., \& Shor, E. (2016). Shades of foreign evil: "Honor killings" and "Family murders" in the canadian press. Violence Against Women, 22(10), 1163-1188.

Thobani, S. (2007). Exalted subjects: Studies in the making of race and nation in Canada. Toronto: University of Toronto Press.

Tuck, E. \& Yang, W. (2012). Decolonization is not a metaphor. Decolonization: Indigeneity, Education, \& Society, 1(1), 1-40. Retrieved from http://www.decolonization.org/index.php/des/article/view/18630 